\title{
PET Radiotracers for CNS-Adrenergic Receptors: Developments and Perspectives
}

\author{
Santosh Reddy Alluri ${ }^{1}$, Sung Won Kim ${ }^{2}$, Nora D. Volkow ${ }^{2,3, *}$ and Kun-Eek Kil ${ }^{1,4, *(\mathbb{C})}$ \\ 1 University of Missouri Research Reactor, University of Missouri, Columbia, MO 65211-5110, USA; \\ srad3k@missouri.edu \\ 2 Laboratory of Neuroimaging, National Institute on Alcohol Abuse and Alcoholism, National Institutes \\ of Health, Bethesda, MD 20892-1013, USA; kims8@mail.nih.gov \\ 3 National Institute on Drug Abuse, National Institutes of Health, Bethesda, MD 20892-1013, USA \\ 4 Department of Veterinary Medicine and Surgery, University of Missouri, Columbia, MO 65211, USA \\ * Correspondence: nvolkow@nida.nih.gov (N.D.V.); kilk@missouri.edu (K.-E.K.); \\ Tel.: +1-(301)-443-6480 (N.D.V.); +1-(573)-884-7885 (K.-E.K.)
}

Academic Editor: Krishan Kumar

Received: 31 July 2020; Accepted: 1 September 2020; Published: 3 September 2020

\begin{abstract}
Epinephrine (E) and norepinephrine (NE) play diverse roles in our body's physiology. In addition to their role in the peripheral nervous system (PNS), E/NE systems including their receptors are critical to the central nervous system (CNS) and to mental health. Various antipsychotics, antidepressants, and psychostimulants exert their influence partially through different subtypes of adrenergic receptors (ARs). Despite the potential of pharmacological applications and long history of research related to E/NE systems, research efforts to identify the roles of ARs in the human brain taking advantage of imaging have been limited by the lack of subtype specific ligands for ARs and brain penetrability issues. This review provides an overview of the development of positron emission tomography (PET) radiotracers for in vivo imaging of AR system in the brain.
\end{abstract}

Keywords: adrenergic receptor; positron emission tomography; radiotracer

\section{Introduction}

Positron emission tomography (PET) is a noninvasive and highly sensitive in vivo imaging technique that uses small amounts of radiotracers to detect the concentration of relevant biomarkers in tissues such as receptors, enzymes, and transporters. These radiotracers can be used to characterize neurochemical changes in neuropsychiatric diseases and also to measure drug pharmacokinetics and pharmacodynamics directly in the human body including the brain [1,2]. PET technology requires positron-emitting radioisotopes, a radiotracer synthesis unit, a PET scanner, and data acquisition components. Among the PET isotopes, cyclotron produced carbon-11 (C-11, $\left.t_{1 / 2}=20.34 \mathrm{~min}\right)$, nitrogen-13 (N-13, $\left.t_{1 / 2}=9.96 \mathrm{~min}\right)$, and fluorine-18 (F-18, $\left.t_{1 / 2}=109.77 \mathrm{~min}\right)$ are frequently used for PET-neuroimaging. PET imaging is particularly valuable to characterize investigational drugs and their target proteins, providing a valuable tool for clinical neuroscience [3].

PET radiotracers for the central nervous system (CNS) should have proper pharmacokinetic profile in the brain and to achieve this property, they were designed to meet five molecular properties: (a) molecular weight $<500 \mathrm{kDa}$, (b) Log $\mathrm{D}_{7.4}$ between $\sim 1$ to 3 (lipophilicity factor), (c) number of hydrogen bond donors $<5$, (d) number of hydrogen bond acceptors $<10$, and (e) topological polar surface area $<90 \AA^{2}$. Otherwise, they may either not cross the blood-brain barrier (BBB) or show lack of specific signal due to high nonspecific binding [3-5]. In addition, an ideal PET radiotracer should have, though unachievable, (a) high affinity (preferably subnanomolar range) for its target, (b) high selectivity between subtypes or void on off-targets, (c) high dynamic range in specific 
binding, (d) appropriate metabolic profile, (e) no adverse toxicology effects, and (f) kinetics suitable for mathematical modelling, which requires fast transfer to BBB and clearance in non-target tissues [3]. In general, a radiotracer with binding potential [ratio of target density $\left(B_{\max }\right)$ to ligand's affinity $\left(K_{\mathrm{d}}\right.$ or $\left.K_{i}\right)$ ] value of at least 10 is expected to provide a reliable specific signal in vivo [6,7]. Furthermore, there are some technical challenges associated with CNS PET radiotracer development, which include: limited synthesis time and/or complex syntheses to prepare a radiotracer, attainment of high molar activity, accurate radiometric metabolite analysis. In addition, the radiotracer ought to ideally address targets that are relevant to brain function and for the diagnosis and therapy of a disease $[3,8]$. Epinephrine (E) and norepinephrine (NE) were discovered in 1894 and 1907, respectively. They are both neurotransmitters and hormones that belong to the group of catecholamines crucial to the function of the body and brain [9-11]. Neither E nor NE crosses the BBB but they are synthetized in the brain. NE is synthesized in synapse from $L$-phenylalanine in four steps enzymatically through phenylalanine hydroxylase (PAH), tyrosine hydroxylase, dopa decarboxylase (DDC), and dopamine beta-hydroxylase $(\mathrm{DBH})$, respectively. Further, NE is methylated to convert into E with phenylethanolamine- $N$-methyl transferase (PNMT) [12-14]. NE in synaptic cleft is removed either by reuptake via NE transporter (NET) or via metabolism by monoamine oxidase A (MAO-A) or catechol-O-methyl transferase (COMT) into various transitional metabolites. Though the noradrenergic neurons are confined to a few relatively small brain areas such as midbrain, pons, locus coeruleus, caudal ventrolateral nucleus, and medulla, they send extensive projections to most brain regions [15]. Table 1 summarizes the brain distribution (reported in mice) and function of various AR subtypes and their involvement in some brain disorders for CNS-ARs.

The effects of NE and E in the CNS and PNS is mediated mainly through two main classes of adrenergic receptors (ARs): alpha-ARs ( $\alpha$-ARs) and beta-ARs ( $\beta$-ARs) [16]. The ARs were first identified in 1948 and pharmacological and molecular cloning techniques since then have identified various subclasses of ARs [17,18]. $\alpha$-ARs are divided into $\alpha 1$ and $\alpha 2$ subclasses, wherein, each of these has three subtypes: $\alpha 1 \mathrm{~A}, \alpha 1 \mathrm{~B}, \alpha 1 \mathrm{D}$ and $\alpha 2 \mathrm{~A}, \alpha 2 \mathrm{~B}, \alpha 2 \mathrm{C}$. The three subtypes of $\beta$-ARs are $\beta 1, \beta 2$, and $\beta 3$ [19]. These receptors in the CNS are G-protein coupled receptors (GPCR) and are implicated in pathophysiology of various diseases, biochemical pathways, and biological functions [18].

Table 1. Brain distribution of AR subtypes and their associated brain disorders.

\begin{tabular}{|c|c|c|c|c|}
\hline $\operatorname{Re}$ & ptor & Distribution & Distinct Functions and Associated Disorders & Ref \\
\hline \multirow{3}{*}{$\alpha 1$} & $\alpha 1 \mathrm{~A}$ & $\begin{array}{l}\text { High levels in olfactory system, hypothalamic } \\
\text { nuclei, and brainstem. Moderate levels in } \\
\text { amygdala, cerebral cortex, and cerebellum }\end{array}$ & $\begin{array}{c}\text { Involved in neurotransmission of NE as well as } \\
\gamma \text {-aminobutyric acid (GABA) and NMDA. } \\
\text { May mediate effects of anti-depressants in treating } \\
\text { depression and obsessive compulsive } \\
\text { disorder (OCD) }\end{array}$ & {$[18,20-24]$} \\
\hline & $\alpha 1 \mathrm{~B}$ & $\begin{array}{c}\text { Thalamic nuclei, lateral nucleus of amygdala, } \\
\text { cerebral cortex, some septal regions, } \\
\text { brain stem regions }\end{array}$ & $\begin{array}{l}\text { May play a role in behavioral activation. } \\
\text { Associated with addiction, and neurodegenerative } \\
\text { disorders (Multiple System Atrophy) }\end{array}$ & {$[18,20,21,24-27]$} \\
\hline & $\alpha 1 \mathrm{D}$ & $\begin{array}{l}\text { Olfactory bulb, cerebral cortex, hippocampus, } \\
\text { reticular thalamic nuclei, and amygdala }\end{array}$ & $\begin{array}{l}\text { Mediates changes in locomotor behaviors. } \\
\text { Associated with stress. }\end{array}$ & {$[18,20,23,28,29]$} \\
\hline \multirow{3}{*}{$\alpha 2$} & $\alpha 2 \mathrm{~A}$ & $\begin{array}{l}\text { Locus coeruleus, midbrain, hypothalamus, } \\
\text { amygdala, cerebral cortex, and brain stem }\end{array}$ & $\begin{array}{l}\text { Mediate functions of most of the } \alpha 2 \text {-agonists used } \\
\text { in sedation, antinociception, and behavioral } \\
\text { actions. Associated with ADHD, anxiety }\end{array}$ & {$[18,23,30-35]$} \\
\hline & $\alpha 2 B$ & $\begin{array}{l}\text { Thalamus, hypothalamus, } \\
\text { cerebellar Purkinje layer }\end{array}$ & Mediate antinociceptive action of nitrous oxide & {$[18,30,31]$} \\
\hline & $\alpha 2 \mathrm{C}$ & $\begin{array}{l}\text { Hippocampus, striatum, olfactory tubercle, } \\
\text { medulla, and basal ganglia }\end{array}$ & $\begin{array}{c}\text { Involved in the neuronal release of NE as well as } \\
\text { dopamine and serotonin. } \\
\text { Potential therapeutic } \\
\text { targets in depression \& schizophrenia }\end{array}$ & {$[18,30,31,36-39]$} \\
\hline \multirow{3}{*}{$\beta$} & $\beta 1$ & \multirow{3}{*}{$\begin{array}{l}\text { Homologous distribution. Expression was } \\
\text { found (mostly } \beta 1 \text { and } \beta 2 \text { ) in frontal cortex, } \\
\text { striatum, thalamus, putamen, amygdala, } \\
\text { cerebellum, cerebral cortex and hippocampus. }\end{array}$} & \multirow{3}{*}{$\begin{array}{l}\text { Essential to motor learning, emotional memory } \\
\text { storage and regulation of neuronal regeneration. } \\
\text { Associated with mood disorders, aging, } \\
\text { Alzheimer's disease, Parkinson's disease. }\end{array}$} & \multirow{3}{*}[16,18,40-48]{} \\
\hline & $\beta 2$ & & & \\
\hline & $\beta 3$ & & & \\
\hline
\end{tabular}


Given its biological significance, the adrenergic system has emerged as an important target for PET studies. Although ARs play major roles in the brain, most PET studies of ARs have focused on cardiac imaging [49,50] and PET studies of CNS-ARs are very limited. The other components of adrenergic system such as NET and MAO-A were studied using PET. Various C-11 and F-18 radiotracers of NET-selective anti-depressants (e.g., reboxetine) were examined using PET to monitor the function of noradrenergic system in CNS. Radiotracers, for example, $(S, S)-\left[{ }^{11} \mathrm{C}\right] \mathrm{O}$-methyl-reboxetine $\left(\left[{ }^{11} \mathrm{C}\right] \mathrm{MRB}\right)$ and $\left[{ }^{18} \mathrm{~F}\right] \mathrm{FMeNER}-\mathrm{D}_{2}$, were shown to exhibit desirable in vivo properties and their regional distribution in the brain is consistent with known distribution of NET in preclinical/clinical settings [51-54]. These radiotracers have been employed to monitor NET availability in different related diseases, including obesity, major depressive disorder, and Parkinson's disease. Likewise, radiotracers, for instance, $\left[{ }^{11} \mathrm{C}\right]$ Harmine demonstrated clinical success for in vivo brain imaging of MAO-A, respectively [55-57]. $\left[{ }^{11} \mathrm{C}\right]$ Harmine has been applied in several-PET neuroimaging studies to study the role of MAO-A in different pathological conditions, including nicotine/alcohol dependence, and Alzheimer's disease.

However, the metabolic functions of MAO-A do not necessarily reflect the activities of adrenergic system as they also metabolize other neurotransmitters, such as, dopamine and serotonin (5-HT). Therefore, the in vivo activities of adrenergic neurons, thus far, were exclusively examined by PET imaging based on NET. Since the activities of NET reflect only on presynaptic systems of adrenergic neurons, novel PET radiotracers that can observe the features of postsynaptic adrenergic system are still required. PET-neuroimaging of AR subtypes combined with NET can scrutinize the unique implications of adrenergic system in various pathophysiological conditions of the brain. Subtype specific PET radiotracers for CNS-ARs have the potential to help clarify the roles of ARs in brain pathophysiology and provide suggestions towards the diagnosis and treatment for diseases such as depression, attention deficit hyperactivity disorder (ADHD), substance use disorders, schizophrenia, and neurodegenerative diseases that involve ARs. This review, based on reports published through 2019, summarizes the development of PET radioligands for CNS-ARs in animal models and human subjects and presents suggestions for further development for CNS-AR radiotracers.

\section{2. $\alpha 1$-AR PET Radiotracers}

Three highly homologous subunits of $\alpha-1$ ARs, $\alpha 1 \mathrm{~A}, \alpha 1 \mathrm{~B}$, and $\alpha 1 \mathrm{D}$, have been shown to have different amino acid sequence, pharmacological properties, and tissue distributions [58-60]. A detailed review of $\alpha 1-A R$ pharmacology is given by Michael and Perez [58]. Binding of NE/E to any of the $\alpha 1$-AR subtypes is stimulatory and activates $G_{q / 11}$-signalling pathway, which involves phospholipase $\mathrm{C}$ activation, generation of secondary messengers, inositol triphosphate and diacyl glycerol and intracellular calcium mobilization. In PNS, as well as in the brain's vascular system it results in smooth muscle contraction and vasoconstriction. While the signaling effects of $\alpha 1$-ARs in the cardiovascular system are well studied [61,62], the role of $\alpha 1$-ARs in CNS is complex and not completely understood. The Bmax values of $\alpha-1$ ARs were measured from saturation assays using $\left[{ }^{3} \mathrm{H}\right]$ prazosin (a selective $\alpha-1$ blocker) with tissue homogenates from rats and the observed binding capacities ( $\mathrm{fmol} / \mathrm{mg}$ tissue) of prazosin in cortex, hippocampus, and cerebellum were $14.49 \pm 0.38,11.03 \pm 0.39$, and $7.72 \pm 0.11$, respectively $[23,63]$. The $\alpha 1$-ARs are postsynaptic receptors and can also modulate release of NE. In the human brain, $\alpha 1$-AR subtypes are localized in amygdala, cerebellum, thalamus, hippocampus, and to some extent in striatum $[20,22,64]$.

The anti-depressant effects of noradrenergic enhancing drugs as well as their effects on anxiety and stress reactivity points to their relevance of $\alpha 1 \mathrm{~A}, \alpha 1 \mathrm{D}$ to these behaviors $[21,28,65]$. Furthermore, $\alpha 1 \mathrm{~A}-\mathrm{ARs}$ regulate GABAergic and NMDAergic neurons [20]. A decrease in $\alpha 1 \mathrm{~A}-\mathrm{AR}$ mRNA expression was observed in prefrontal cortex of subjects with dementia [66,67]. The $\alpha 1 B$-ARs has also been shown to be crucial to brain function and disease [18]. For example, $\alpha 1 \mathrm{~B}-\mathrm{knockout}(\mathrm{KO})$ mice study revealed that $\alpha 1 \mathrm{~B}-\mathrm{AR}$ modulates behavior, showing increased reaction to novel situations [24,27]. In addition, the locomotor and rewarding effects of psychostimulants and opiates were decreased in $\alpha 1 \mathrm{~B}-\mathrm{KO}$ mice, highlighting their role in the pharmacological effects of these drugs [24]. On the other 
hand, studies using the $\alpha 1 \mathrm{~B}$-overexpression model suggest their involvement in neurodegenerative diseases [25].

Several $\alpha 1$-AR agonists and antagonists ( $\alpha 1$-blockers) are available in the market as drugs to treat various heart and brain disorders [68,69]. Pharmacology of most of these drugs is complicated by the fact that they have strong affinities for other receptor systems, such as serotonin and dopamine receptors. The need to develop $\alpha 1$-AR selective/ $\alpha 1$-AR subtype specific drugs is demanding. Undoubtedly, PET radiotracers selective for $\alpha 1$-AR are valuable to assess $\alpha 1$-ARs contribution to brain function and disease. In the late 1980s, prazosin, used for the treatment of hypertension, was labelled with carbon-11 to image $\alpha 1$-ARs with PET [49]. Following this, $\left[{ }^{11} \mathrm{C}\right]$ prazosin analogous, $\left[{ }^{11} \mathrm{C}\right]$ bunazosin and $\left[{ }^{11} \mathrm{C}\right] \mathrm{GB} 67$ (Figure 1A) were developed as PET radiotracers to image $\alpha 1$-ARs in the cardiovascular system $[49,70]$. These tracers were shown to have limited BBB permeability and were deemed to be not suitable for PET-neuroimaging. Efforts to develop PET radiotracers to image $\alpha 1$-ARs in the CNS was mainly based on antipsychotic drugs such as clozapine, sertindole, olanzapine, and risperidone that have mixed binding affinities for $\mathrm{D}_{2}, 5 \mathrm{HT}_{2 \mathrm{~A}}$ receptors and $\alpha 1$-ARs in the nanomolar range. Their affinity for $\alpha 1$-ARs has been shown to contribute to antipsychotic efficacy uncovering their role in psychoses [71,72].

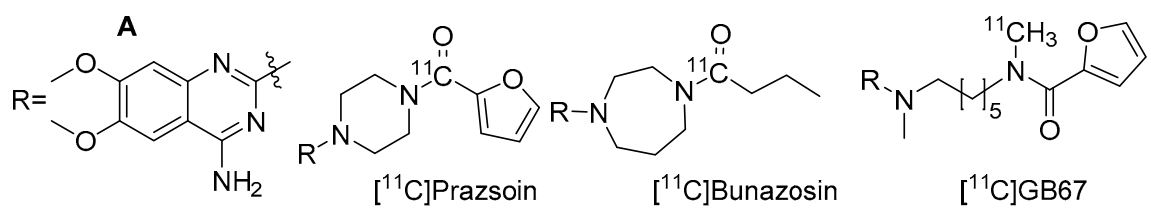<smiles>O=C1NCCN1CC1CCC(c2cn(-c3ccc(F)cc3)nc2-c2ccc(Cl)cc2)CC1</smiles>

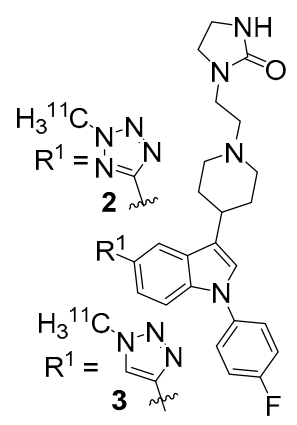

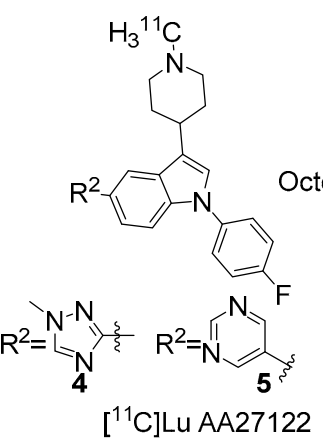

B

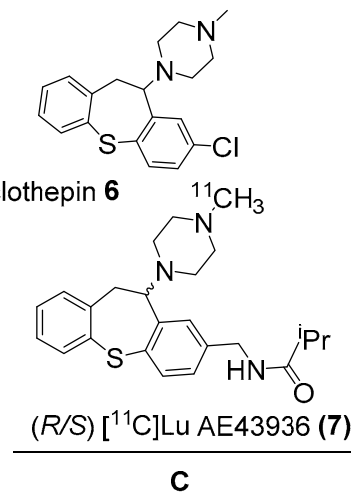

Figure 1. (A) Earlier PET radiotracers, $\left[{ }^{11} \mathrm{C}\right]$ Prazosin, $\left[{ }^{11} \mathrm{C}\right] \mathrm{Bunazosin}$, and $\left[{ }^{11} \mathrm{C}\right] \mathrm{GB} 67$ for cardiac $\alpha 1-\mathrm{AR}$ imaging. (B) Antagonist PET radiotracers based on sertindole. (C) Antagonist PET radiotracers based on octoclothepin for brain $\alpha 1-\mathrm{AR}$ imaging.

Two C-11 labelled analogs of the atypical antipsychotic drug sertindole were first reported by Balle et al. In the early 2000s (Figure 1B) [73,74]. Several other analogs with good affinities $\left(K_{\mathrm{i}}<10 \mathrm{nM}\right)$ for $\alpha 1$-ARs were subsequently reported by the same group. Two analogs, in which chlorine in sertindole (1) is replaced by a 2-methyl-tetrazol-5-yl (2) and a 1-methyl-1,2,3-triazol-4-yl (3), were labelled with C-11 [73,74]. The in vitro affinities $\left(K_{\mathrm{i}}\right)$ of $\mathbf{1}, \mathbf{2}$ and $\mathbf{3}$ for $\alpha 1$-ARs are 1.4, 1.8 and $9.5 \mathrm{nM}$, respectively. Both $\left[{ }^{11} \mathrm{C}\right] 2$ and $\left[{ }^{11} \mathrm{C}\right] 3$ were prepared using ${ }^{11} \mathrm{C}$-methylation with $\left[{ }^{11} \mathrm{C}\right]$ methyl triflate from their corresponding $N$-desmethyl precursors. The molar activity of $\left[{ }^{11} \mathrm{C}\right] 2$ and $\left[{ }^{11} \mathrm{C}\right] 3$ was reported at $70 \mathrm{GBq} / \mu \mathrm{mol}$ and $15 \mathrm{GBq} / \mu \mathrm{mol}$, respectively. Their brain distribution examined with PET in Cynomolgus monkeys showed that brain uptake of $\left[{ }^{11} \mathrm{C}\right] 2$ and $\left[{ }^{11} \mathrm{C}\right] 3$ was slow and low, with $\left[{ }^{11} \mathrm{C}\right] 3$ showing somewhat higher brain uptake than $\left[{ }^{11} \mathrm{C}\right] 2$. Their brain distribution was homogenous and specific binding to $\alpha 1$-ARs could not be demonstrated. It was also concluded that these two radiotracers were not suitable to image $\alpha 1$-ARs in brain owing to rapid metabolism, substantial distribution to other organs, and substrates for active efflux mechanism. 
In the early 2010s, further optimization of structure-activity relationship (SAR) studies led to the identification of two more sertindole analogs, 4 and 5 (Lu AA27122), with higher $\alpha 1-A R$ selectivity over $\mathrm{D}_{2}$ receptors (Figure $\left.1 \mathrm{~B}\right)$. Compared to the in vitro affinity for $\alpha 1 \mathrm{~A}-\mathrm{AR}$ subtype $\left(K_{\mathrm{i}}=0.16,0.52 \mathrm{nM}\right.$ for 4 and 5 ), the affinity for the $\alpha 1 \mathrm{~B}$ and $\alpha 1 \mathrm{D}$ subtypes is 4 to 15 times less potent (Table 2). The LogD7.4 values for 4 (2.7) and 5 (1.9) were in the optimal range for in vivo brain imaging [75-77]. Both [ $\left.{ }^{11} \mathrm{C}\right] 4$ and $\left[{ }^{11} \mathrm{C}\right] 5$ were prepared in a similar manner like above with $>370 \mathrm{GBq} / \mu \mathrm{mol}$ molar activity for non-human primate studies [75]. Interestingly, while $\left[{ }^{11} \mathrm{C}\right] 4$ showed very poor brain uptake, $\left[{ }^{11} \mathrm{C}\right] 5$ had suitable brain uptake (4.6\% ID/cc at $36 \mathrm{~min})$. However, its binding was not blocked with a pharmacological dose of prazosin pretreatment, indicating lack of $\alpha 1-\mathrm{AR}$ specificity.

Table 2. In vitro affinities of compounds 1 to 7 for $\alpha 1-\mathrm{ARs}, \mathrm{D}_{2}$ and $5 \mathrm{HT}_{2 \mathrm{C}}$ receptors $[73,75,76]$.

\begin{tabular}{cccccc}
\hline Compound & \multicolumn{5}{c}{ Receptor $\boldsymbol{K}_{\mathbf{i}}$ (nM) } \\
\hline & $\alpha 1 \mathrm{~A}$ & $\alpha 1 \mathrm{~B}$ & $\alpha 1 \mathrm{D}$ & $\mathrm{D}_{2}$ & $5 \mathrm{HT}_{2 \mathrm{C}}$ \\
\hline $\mathbf{1}$ & 0.37 & 0.33 & 0.66 & 0.45 & 0.55 \\
$\mathbf{2}$ & 0.23 & 1.1 & 2.0 & 140 & 330 \\
$\mathbf{3}$ & 3.0 & 6.0 & 8.6 & 310 & 1500 \\
$\mathbf{4}$ & 0.16 & 6.4 & 15 & 220 & - \\
$\mathbf{5}$ & 0.52 & 1.9 & 2.5 & 120 & - \\
$\mathbf{6}$ & 0.37 & 0.33 & 0.66 & 0.45 & 0.51 \\
$(R)-\mathbf{7}$ & 0.43 & 0.27 & 0.64 & 31 & 8.0 \\
$(S)-7$ & 0.16 & 0.20 & 0.21 & 4.5 & 93 \\
\hline
\end{tabular}

At the same time, another C-11 labelled radiotracer, $\left[{ }^{11} \mathrm{C}\right] 7$ ([11 C]Lu AE43936, Figure $\left.1 \mathrm{C}\right)$ for brain $\alpha 1$-ARs was developed and evaluated by Risgaard et al. [76]. This radiotracer was based on the antipsychotic octoclothepin (6, Figure 1C), which belongs to the tricylic dibenzotheiepin group and has inverse agonist effects at dopamine, serotonin, and $\alpha 1$ receptor sites [78]. Two enantiomers of $7(R / S)$ were radiolabelled on the basis of their varying selectivity and specificity for $\alpha 1$-AR subtypes (Table 2) and imaged with PET in female Danish Landrace pigs. The baseline PET imaging results indicated that neither of the radiolabelled isomers entered the pig's brain. Pretreatment with cyclosporin A (CsA) [79] increased the brain uptake of $(R)-7$ in $\alpha 1$-AR rich cortex, thalamus (above 2 SUV), suggesting that $(R)-7$ was a substrate for active efflux transporters. Further cell studies specified that $(R)-7$ is a substrate for p-glycoprotein (Pgp).

So far, none of the reported radiotracers showed promising results for in vivo brain imaging of $\alpha 1-A R s$ for they were limited by poor BBB penetration, being substrates of Pgp or lack of binding specificity. Therefore, novel $\alpha 1-A R$ radiotracers that overcome brain permeability and display good affinity and subtype-selectivity are required to evaluate the role of $\alpha 1$-AR subtypes in brain pathophysiology. Several $\alpha 1-A R$ subtype specific (high affinity for one subtype over the other) and nonspecific compounds have been reported over the years [26,29,80,81]. Either direct radiolabeling (if possible) or chemical modification and then radiolabeling of the most specific compounds could be an optimal approach for developing new $\alpha 1$-subtype specific radiotracer, considering the aforementioned CNS-PET radiotracer criteria.

\section{3. $\alpha 2$-AR Subtype and Nonspecific PET Radiotracers}

Unlike $\alpha 1$-ARs, $\alpha 2$-ARs decrease adenyl cyclase activity in association with $\mathrm{G}_{\mathrm{i}}$ heterotrimeric G-protein and hence are inhibitory. They mediate many NE effects including cognition and readiness for action [11,30]. The brain distribution of the three subtypes, $\alpha 2 \mathrm{~A}, \alpha 2 \mathrm{~B}$, and $\alpha 2 \mathrm{C}$, was characterized by autoradiography and immunohistochemistry techniques. Among the three subtypes, $\alpha 2 \mathrm{~A}-\mathrm{ARs}$ are the most abundant in the brain and localized in locus coeruleus, midbrain, hippocampus, hypothalamus, amygdala, cerebral cortex and brain stem. The $\alpha 2 \mathrm{~B}-\mathrm{ARs}$ are located in thalamus and hypothalamus and $\alpha 2 C$-ARs in cortex, hippocampus, olfactory tubercle and basal ganglia [51-53]. In the mouse 
brain, $\sim 90 \%$ of $\alpha 2$-ARs are $\alpha 2$ A-ARs and $~ 10 \%$ are $\alpha 2$ C-ARs [30-32,82]. Notably, binding experiments using $\left[{ }^{3} \mathrm{H}\right] 2$-methoxyidazoxan (a selective $\alpha$-2 AR antagonist) with postmortem human brain detected $100 \%$ of $\alpha 2 \mathrm{~A}-\mathrm{ARs}$ population in the hippocampus, cerebellum, and brainstem $\left(B_{\max }=34-90 \mathrm{fmol} / \mathrm{mg}\right.$ protein). In addition to this, $\alpha 2 \mathrm{~A}-\mathrm{AR}\left(B_{\max }=53 \mathrm{fmol} / \mathrm{mg}\right.$ of protein) and $\alpha 2 \mathrm{~B} / \mathrm{C}-\mathrm{AR}\left(B_{\max }=8 \mathrm{fmol} / \mathrm{mg}\right.$ of protein) were detected in the frontal cortex [30]. An extensive array of agonists and antagonists for $\alpha 2$-ARs have been developed. The main limitation of these ligands is lack of subtype selectivity for $\alpha 2$-ARs and off-target binding to other receptors [83,84]. $\alpha 2 \mathrm{~A}$-ARs are mostly presynaptic and agonists inhibit NE release from the terminals and are used to treat hypertension, drug withdrawal, and ADHD whereas antagonists increase NE release and are used as antidepressants. Development of $\alpha 2$-AR subtype selective PET tracers would facilitate medication development and help gain further understanding of their role in brain diseases.

During the 1980s, two research groups identified two potent $\alpha 2$-AR selective antagonists via radioligand binding assays. One WY-26703 belongs to the benzoquinolizine class, and the other MK-492 belongs to the benzo[b]furo-quinolizine class $[85,86]$. Based on these templates, Bylund's group developed two PET tracers: $\left[{ }^{11} \mathrm{C}\right] W Y-26703$ (8) in 1992 and [ $\left.{ }^{11} \mathrm{C}\right] \mathrm{MK}-912$ (9) in 1998 (Figure 2) [87,88]. Both radiotracers were prepared from their respective $\mathrm{N}$-desmethyl precursors via ${ }^{11} \mathrm{C}$-methylation with 30.71-34.41 GBq/ $\mu \mathrm{mol}$ molar activity. The in vitro binding assays and ex vivo biodistribution studies (tissue dissection followed by $\gamma$-counting) in rodents indicated that both radiotracers crossed the BBB and 9 showed higher affinity and specific binding to $\alpha 2$-ARs than 8 . However, PET studies of $\mathbf{8}$ and $\mathbf{9}$ in Rhesus monkeys showed fast washout from brain and nonspecific binding; thus it was concluded that they were not appropriate for PET imaging of $\alpha 2$-ARs in brain.

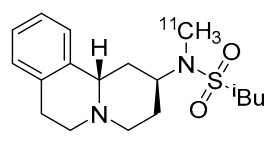

$\left[{ }^{11} \mathrm{C}\right] \mathrm{WY}-26703,8$

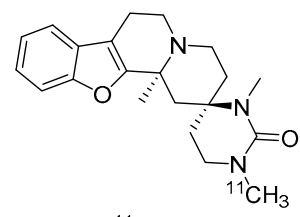

$\left[{ }^{11} \mathrm{C}\right] \mathrm{MK}-912,9$

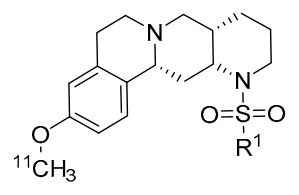

$\left[{ }^{11} \mathrm{C}\right] \mathrm{RS}-15385-197,10\left(\mathrm{R}^{1}=\mathrm{Me}\right)$

$\left[{ }^{11} \mathrm{C}\right] \mathrm{RS}-79948-197,11\left(\mathrm{R}^{1}=\mathrm{Et}\right)$

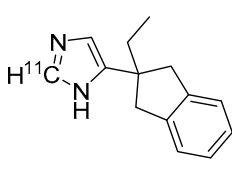

12

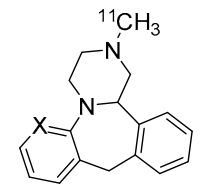

$\left[{ }^{11} \mathrm{C}\right]$ mianserin, $13(X=\mathrm{CH})$ $\left[{ }^{11} \mathrm{C}\right]$ mitrazepine, $14(X=N)$

Figure 2. Various classes of $\alpha 2$-ARs antagonist radiotracers.

In 1997, Pike's group developed $\left[{ }^{11} \mathrm{C}\right] \mathrm{RS}-15385-197(\mathbf{1 0})$ and $\left[{ }^{11} \mathrm{C}\right] 79948-197(\mathbf{1 1})$ as PET $\alpha 2-\mathrm{ARs}$ ligands (Figure 2) [89]. These radiotracers were prepared from their respective $O$-desmethyl precursors through the ${ }^{11} \mathrm{C}$-methylation method with $61 \pm 17 \mathrm{GBq} / \mu \mathrm{mol}(\mathbf{1 0})$ and $64 \pm 3 \mathrm{GBq} / \mu \mathrm{mol}$ molar activity (11). Biodistribution, brain uptake, and metabolic profile studies were done in male Sprague-Dawley rats. They observed specific signals in brain (mainly cerebellum) at 30-90 min (70-95\% radioactivity of parent radioligand), which was analogous to their results with $\left[{ }^{3} \mathrm{H}\right] \mathbf{1 0}$. Nonspecific binding in brain was $\mathbf{1 1}>\mathbf{1 0}$, which mostly likely reflected their differential metabolism $(\mathbf{1 1}>\mathbf{1 0})$. Thus, they chose 10 to quantify $\alpha 2$-ARs in the human brain using PET [90]. Studies in two volunteers with $\mathbf{1 0}$ revealed a low brain uptake index (BUI) due to high affinity to human plasma proteins. Consequently, $\mathbf{1 0}$ was not studied further.

In 2002, Crouzel's group chose atipamezole, an $\alpha 2$-AR selective antagonist, to develop $\left[{ }^{11} \mathrm{C}\right.$ ]atipamezole, 12 (Figure 2) [91]. The radiotracer was prepared through an unique approach using 2-ethyl-2-oxoacetylindane, $\left[{ }^{11} \mathrm{C}\right]$ formaldehyde $\left(\left[{ }^{11} \mathrm{C}\right] \mathrm{HCHO}\right)$ in the presence of zinc oxide and ammonium hydroxide (similar to Debus-Radziszewski imidazole synthesis) with an overall yield of 1.5\%. However, no PET studies were reported with 12.

Furthermore, in 2002, Smith's group developed two tetracyclic based anti-depressant radiotracers, mianserin (13) and mitrazepine (14), that have potent antagonist properties at $\alpha 2$-ARs and also at serotonin receptors $\left(5 \mathrm{HT}_{2 \mathrm{~A}}, 5 \mathrm{HT}_{2} \mathrm{C}\right)$ and labelled them with $\mathrm{C}-11$ to prepare $\mathbf{1 3}$ and $\mathbf{1 4}$ (Figure 2) $[92,93]$. The radiotracers 13 and $\mathbf{1 4}$ were prepared from their respective $N$-desmethyl precursors via ${ }^{11} \mathrm{C}$-methylation with $\sim 40 \mathrm{GBq} / \mu \mathrm{mol}$ and $5-7 \mathrm{GBq} / \mu \mathrm{mol}$ molar activity, respectively. PET studies in female pigs with $\mathbf{1 3}$ showed limited binding potential in brain whereas $\mathbf{1 4}$ showed more favorable 
properties including slow metabolism, fast brain uptake and sufficient target-to-background ratio for pharmacokinetic parameters estimation.

Radiotracer $\mathbf{1 4}$ had higher binding in the frontal cortex, thalamus, and basal ganglia where pretreatment with unlabeled mitrazepine revealed that its binding was reversible, whereas, in the cerebellum and olfactory tubercle, it was not. Notably, using the $\alpha 2$-AR subtype KO mouse model they validated the receptor selectivity of $\mathbf{1 4}$. In 2004 and 2009, this group conducted a clinical trial with volunteers using 14 to study its distribution, metabolism and pharmacokinetics [94,95]. The results revealed that $\mathbf{1 4}$ can serve as a PET radiotracer to image $\alpha 2$-ARs in the brain, though identification of its metabolites and its nonselective binding are limitations.

Two years later, Leysen's group developed a reversible, potent and selective $\alpha 2$-AR antagonist, viz. R107474 (15, Figure 3) [96]. They prepared [ $\left.{ }^{11} \mathrm{C}\right] 15$ through Pictet-Spengler condensation method using $\left[{ }^{11} \mathrm{C}\right] \mathrm{HCHO}$ and the respective secondary amine with $24-28 \mathrm{GBq} / \mu \mathrm{mol}$ molar activity at the end of bombardment (EOB). They carried out ex vivo autoradiography to measure in vivo $\alpha 2 \mathrm{~A}$-ARs and $\alpha 2 \mathrm{C}$-ARs occupancy of $\mathbf{1 5}$ in rats. Biodistribution studies showed rapid uptake of $\mathbf{1 5}$ into brain and other tissues with the brain showing the highest uptake other than liver and kidneys. In the brain the highest uptake of 15 was in the septum $(3.54 \pm 0.52 \mathrm{ID} / \mathrm{g})$ and entorhinal cortex $(1.57 \pm 0.50 \mathrm{ID} / \mathrm{g})$ whereas the lowest was in the cerebellum, a region with very low density of $\alpha 2$-ARs. However, the potential of $\mathbf{1 5}$ was not investigated further.
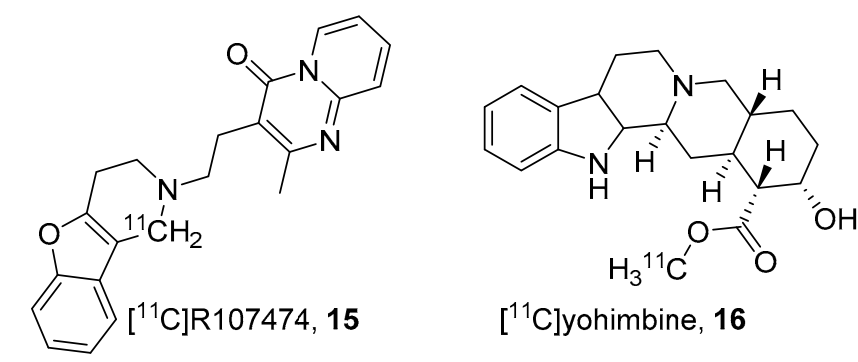

$\left[{ }^{11}\right.$ C]yohimbine, 16

Figure 3. Anti-depressive \& antihypertensive based $\alpha 2$-AR PET radiotracers.

In 2006, Jacobsen's group developed C-11 labelled yohimbine (16, Figure 3) [97], an antihypertensive agent. Yohimbine has potent antagonist properties at $\alpha 2$-ARs, but also interacts with $\alpha 1$ and 5-hydroxy tryptamine $1 \mathrm{~A}$ receptors $\left(5-\mathrm{HT}_{1 \mathrm{~A}}\right)$. The radiotracer $\mathbf{1 6}$ was prepared through ${ }^{11} \mathrm{C}$-methylation of yohimbinic acid using $\mathrm{C}-11$ methyl iodide $\left(\left[{ }^{11} \mathrm{C}_{\mathrm{C}} \mathrm{CH}_{3} \mathrm{I}\right)\right.$ and obtained with $40 \mathrm{GBq} / \mu \mathrm{mol}$ molar activity.

PET studies were performed in pigs to obtain whole-body and dosimetry recordings and for dynamic brain imaging. Interestingly, no radioactive metabolites of $\mathbf{1 6}$ were reported in pig plasma and binding of $\mathbf{1 6}$ was observed in $\alpha 2$-AR-rich regions where it was displaceable by co-injection of pharmacological doses of yohimbine or selective $\alpha 2$-AR antagonist (Figure 4). Later, $\mathbf{1 6}$ was used to image $\alpha 2$-ARs in the human brain $(n=6)$ using PET [98]. Highest binding of $\mathbf{1 6}$ was observed in cortex and hippocampus and the lowest in corpus callosum, which was used as a reference region to estimate the average total distribution $\left(V_{\mathrm{T}}\right)$ in other brain regions. The radiotracer 16 seems to be a suitable radiotracer to image $\alpha 2$-ARs but has similar issues as of $\mathbf{1 4}$, which need to be addressed.

The concentration of $\alpha 2$-subtype receptors in the brain is low (5-90 fmol/mg range) increasing the challenge for their detection by PET [31]. Therefore, $\alpha 2$ - subtype specific PET tracers (with subnanomolar affinities and $>30$-fold selectivity) still need to be developed for the quantification of $\alpha 2$-subtype receptors and to assess their role in brain diseases. A few research groups have developed $\alpha 2$-subtype specific PET radiotracers, but success has been limited. 


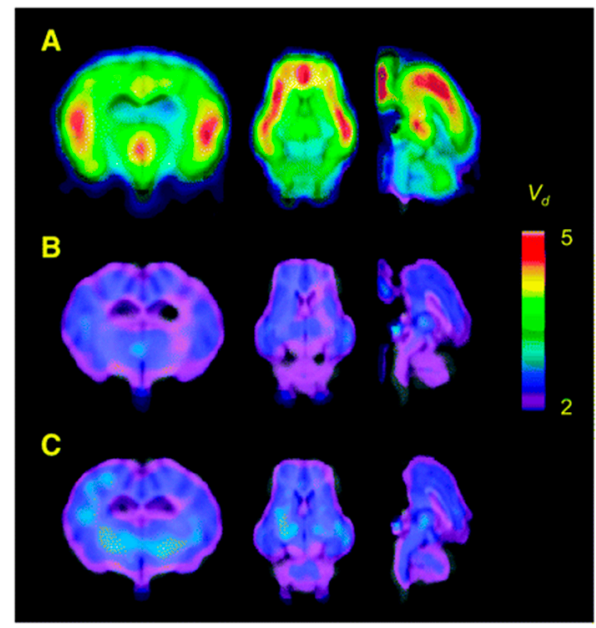

Figure 4. Parametric maps of $\mathbf{1 6}$ in living porcine brain. (A) Baseline study using $\mathbf{1 6}$ showed regional differences in its distribution. (B) Blocking experiment (yohimbine at $0.07 \mathrm{mg} / \mathrm{kg}$ ) reduced the scale of distribution volume $\left(V_{\mathrm{d}}\right)$ to $\sim 2 \mathrm{~mL} \mathrm{~g}^{-1}$ in all the $\alpha 2$-AR bound regions. (C) Increased dose of yohimbine $(1.6 \mathrm{mg} / \mathrm{kg})$ had no further significant effect in comparison to the low dose $(n=3)$ Maps are superimposed on the MR image. Adapted from JNM publication by Jacobsen S, Pedersen, K.; Smith, D.F.; Jensen, S.B.; Munk, O.L.; Cumming P [97]. Permission obtained from SNMMI.

\section{1. $\alpha 2$ A-Specific PET Radiotracers}

Kumar's group in 2010 developed $\left[{ }^{11} \mathrm{C}\right] \mathrm{MPTQ}(\mathbf{1 7}$, Figure 5) for the quantification of $\alpha 2 \mathrm{~A}$-ARs in vivo [35]. Compound 17 was shown to have blocking effects on $\alpha 2 \mathrm{~A}-\mathrm{ARs}$ in vivo in brain and has stronger affinities for $\alpha 2 \mathrm{~A}-\mathrm{AR}\left(K_{\mathrm{i}}=1.6 \mathrm{nM}\right)$ than $\alpha 2 \mathrm{C}-\mathrm{AR}\left(K_{\mathrm{i}}=4.5 \mathrm{nM}\right)$ and 5-HTT (serotonin transporter, $K_{\mathrm{i}}=16 \mathrm{nM}$ ) [99]. They anticipated no binding of 17 to $\alpha 2 \mathrm{~B}$ and $\alpha 2 \mathrm{C}$-ARs since the densities of these receptors are lower than $\alpha 2 \mathrm{~A}$-ARs. In addition, the 10-fold higher affinity of $17 \alpha 2 \mathrm{~A}$-ARs over 5-HTT is advantageous for $\alpha 2 \mathrm{~A}$-ARs as both have similar $B_{\max }$ values. The radiosynthesis of $\mathbf{1 7}$ was accomplished through ${ }^{11} \mathrm{C}$-methylation of its respective $N$-desmethyl precursor with $74-88.8 \mathrm{GBq} / \mu \mathrm{mol}$ molar activity at the end of synthesis (EOS). PET studies in baboons with $\mathbf{1 7}$ showed that it penetrated the BBB and accumulated in $\alpha 2 \mathrm{~A}-\mathrm{AR}$-rich brain areas. They ruled out binding of $\mathbf{1 7}$ to 5 -HTT due to its low uptake in the hippocampus, temporal cortex, and occipital cortex, which are the brain regions with the highest binding of 5-HTT radiotracers. No further studies were reported using 17.

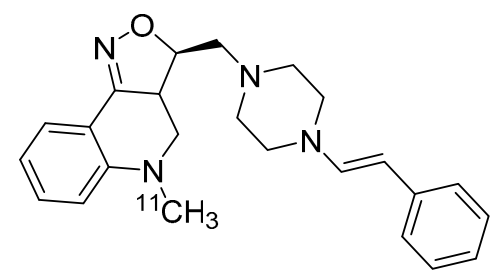

$\left[{ }^{11} \mathrm{C}\right] \mathrm{MPTQ}, 17$<smiles>[18F]c1ccc2c(cnn2N=C2NCCN2)c1</smiles>

6-[ $\left[{ }^{18} \mathrm{~F}\right]$ fluoromarsanidine, 18

Figure 5. $\alpha 2 \mathrm{~A}$-antagonist (17) and agonist (18) PET radiotracers.

In search of a selective agonist to $\alpha 2$-ARs, Lehmann's group identified 1-[(imidazolidin-2-yl) imino]indazole (marsanidine) [100] and later developed an $\alpha 2 \mathrm{~A}$ subtype specific ligand by introducing fluorine to marsanidine [33]. The reported binding affinity $\left(K_{\mathrm{d}}\right)$ of 6 -fluoromarsanidine for $\alpha 2 \mathrm{~A}(33 \mathrm{nM})$ is higher than for $\alpha 2 B(72 \mathrm{nM})$ and $\alpha 2 \mathrm{C}(600 \mathrm{nM})$. Solin et al., in 2019, prepared 6- $\left[{ }^{18} \mathrm{~F}\right]$ fluoromarsanidine (18, Figure 5) through electrophilic ${ }^{18} \mathrm{~F}$-radiofluorination using $\left[{ }^{18} \mathrm{~F}\right]$ selectfluor bis(triflate) and a corresponding precursor with 3-26 GBq/ $\mu \mathrm{mol}$ molar activity at the EOS [34]. In vivo PET was performed in rats and $\alpha 2 \mathrm{~A}-\mathrm{KO}$ mice, but the radiotracer was not continued further because of its rapid metabolism and high nonspecific uptake in rat and mouse brain. 


\section{2. $\alpha 2$ C-Specific PET Radiotracers}

Animal models, such as the forced swimming test (FST) and the prepulse inhibition (PPI) are used to screen for anti-depressants and anti-psychotics, respectively. The use of $\alpha 2 \mathrm{C}-\mathrm{KO}$ and $\alpha 2 \mathrm{C}$-overexpression ( $\alpha 2 \mathrm{C}$-OE) mouse models in FST and PPI paradigms suggested that $\alpha 2 \mathrm{C}$-specific compounds may have therapeutic benefits for depression and schizophrenia [32,38]. In 2007, Orion pharma from Finland identified an acridine-based compound, JP-1302 [38], and a research group from Japan identified a methyl benzofuran based compound, MBF [101], as selective $\alpha 2 \mathrm{C}$ antagonists. Both these ligands have high affinities for $\alpha 2 \mathrm{C}\left(\mathrm{JP}-1302 K_{\mathrm{i}}=28 \mathrm{nM}, \mathrm{MBF} K_{i}=20 \mathrm{nM}\right)$ than for $\alpha 2 \mathrm{~A}$ $\left(\mathrm{JP}-1302 K_{\mathrm{i}}=3500 \mathrm{nM}, \mathrm{MBF} K_{\mathrm{i}}=17,000 \mathrm{nM}\right)$ and $\alpha 2 \mathrm{~B}\left(\mathrm{JP}-1302 K_{\mathrm{i}}=1500 \mathrm{nM}, \mathrm{MBF} K_{\mathrm{i}}=750 \mathrm{nM}\right)$. Based on these findings, Zhang's group, in 2010, synthesized [ $\left.{ }^{11} \mathrm{C}\right] J \mathrm{P}-1302(\mathbf{1 9})$ and $\left[{ }^{11} \mathrm{C}\right] \mathrm{MBF}(20)($ Figure 6) as PET probes to evaluate their BBB penetration and $\alpha 2 \mathrm{C}$ selective binding in the brain [37]. The radiotracers 19 (molar activity $95 \pm 24 \mathrm{GBq} / \mu \mathrm{mol}$ ) and 20 (molar activity $62 \pm 15 \mathrm{GBq} / \mu \mathrm{mol}$ ) were prepared using ${ }^{11} \mathrm{C}$-methylation from $\mathrm{N}$-desmethyl and $\mathrm{O}$-desmethyl precursors, respectively. PET studies were conducted in WT and Pgp, breast cancer resistance protein (BCRP) KO mice using both radiotracers.

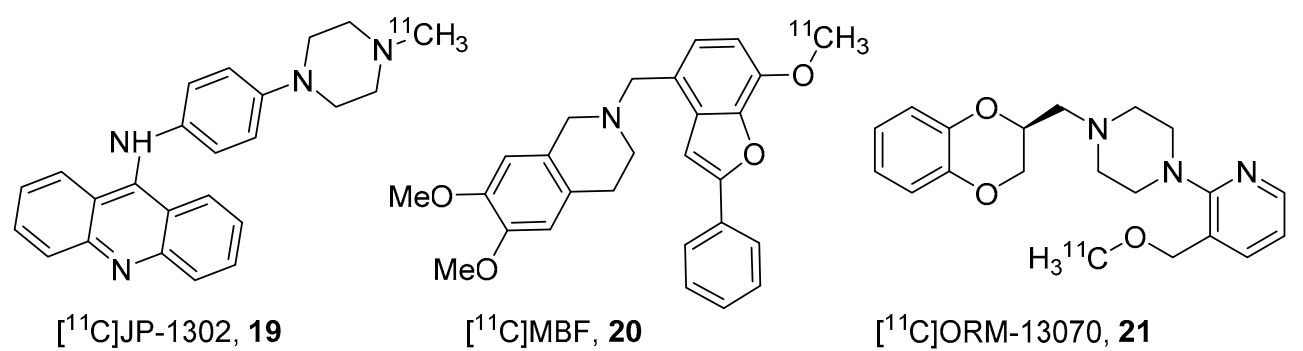

Figure 6. PET radiotracers for $\alpha 2 \mathrm{C}$-ARs.

This combined KO model is useful to evaluate whether brain penetration of PET probes is sensitive to Pgp and BCRP. After injection of the radiotracers, their levels in the brain were low in WT mice whereas they were higher in Pgp and BCRP KO mice. The regional binding of these radiotracers did not correspond with the regional brain distribution of $\alpha 2 C$, so it was concluded that they were inadequate to evaluate $\alpha 2 \mathrm{C}$-ARs in brain with PET.

In 2014, researchers from Turku PET center and Orion Pharma reported the radiosynthesis of [ ${ }^{11} \mathrm{C}$ ]ORM13070 (21, Figure 6) with molar activity $690 \pm 340 \mathrm{GBq} / \mu \mathrm{mol}$ and its evaluation in rats and in $\alpha 2 \mathrm{~A}$ and $\alpha 2 \mathrm{AC}$ KO mice with PET [36,102]. The binding affinities of $\mathbf{2 1}$ for $\alpha 2 \mathrm{C}(3.8 \mathrm{nM})$ is higher than for $\alpha 2 \mathrm{~A}(109 \mathrm{nM})$ and $\alpha 2 \mathrm{~B}(23 \mathrm{nM})$.

The in vivo PET and ex vivo autoradiography of 21 in rat indicated that its brain distribution corresponds to the regional distribution of $\alpha 2 \mathrm{C}$ in brain, with highest levels in striatum and olfactory tubercle. Pretreatment with atipamezole, a $\alpha 2$-sutype nonselective antagonist blocked the binding of 21 into these regions. Furthermore, by using $\alpha 2 \mathrm{~A}$ and $\alpha 2 \mathrm{AC} \mathrm{KO}$ model mice, they demonstrated $\alpha 2 \mathrm{C}$ specificity of 21. The brain uptake of 21 in $\alpha 2 \mathrm{~A}-\mathrm{KO}$ and WT mice was similar whereas, negligible uptake occurred in $\alpha 2 \mathrm{AC} \mathrm{KO}$ (Figure 7, left). They represented time-activity curves for striatum and cerebellar cortex of three mice types (Figure 7, right) and the radioactivity ratios at 5-15 min for $\alpha 2 \mathrm{~A}, \alpha 2 \mathrm{AC} \mathrm{KO}$ mice, and WT mice were 1.51-1.51, 1.06-1.09 and 1.51-1.57, respectively.

Accordingly, 21 was studied in healthy men to estimate its metabolism, pharmacokinetics, whole-body distribution and radiation dosimetry [39]. Good results were obtained in rodent and human PET studies with 21, except for its fast washout from brain. Better pharmacokinetics, higher affinity, and specificity can potentially be enhanced by structural modifications to 21 . Given that the $\alpha 2 \mathrm{~A}$-ARs are widely distributed in brain in contrast to $\alpha 2 \mathrm{C}$-ARs, a candidate with subnanomolar affinity for $\alpha 2$ C-ARs ( $>50$-fold affinity than $\alpha 2 \mathrm{~A}$-ARs) is needed for a PET radiotracer. As $\alpha 2 \mathrm{C}$-ARs are of interest as therapeutic targets in brain diseases, the $\alpha 2 \mathrm{C}$-specifc PET radiotracers would facilitate their development as medications and help in investigations of $\alpha 2 \mathrm{C}$-ARs in the human brain. 

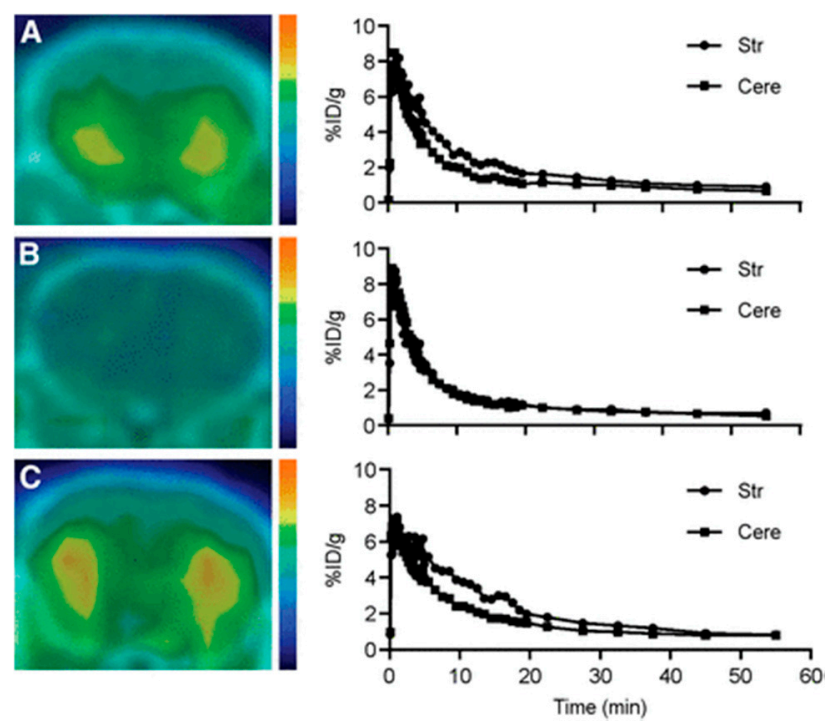

Figure 7. PET/CT images and time-activity curves of 21 for striatum and cerebellar cortex of (A) $\alpha 2 \mathrm{~A}$ $\mathrm{KO}(\mathrm{B}) \alpha 2 \mathrm{AC} \mathrm{KO}$ and (C) WT mice. Brain uptake of 21 in $\alpha 2 \mathrm{AC} \mathrm{KO}$ is negligible and is similar in $\alpha 2 \mathrm{~A}$ $\mathrm{KO}$ and WT mice with $7.8-8.1 \% \mathrm{ID} / \mathrm{g}$ at $1 \mathrm{~min}$ and $1.2 \% \mathrm{ID} / \mathrm{g}$ at $30 \mathrm{~min}$ after 21 injection. The striatum to cerebellar cortex radioactivity ratios (at 5-15 min) for $\alpha 2 \mathrm{AC} \mathrm{KO}$ mice did not differ and for $\alpha 2 \mathrm{~A}$ KO and WT mice are alike. Adapted from JNM publication by Arponen E.; Helin, S.; Marjamäki, P.; Grönroos, T.; Holm, P.; Löyttyniemi, E.; Någren, K.; Scheinin, M.; Haaparanta-Solin, M.; Sallinen, J.; [36]. Permission obtained from SNMMI.

\section{4. $\beta$-ARs and Nonselective PET Radiotracers}

$\beta$-ARs are associated with $G_{s}$-heterotrimeric $G$-protein and mediate intracellular signaling through adenyl cyclase activation and cyclic adenosine monophosphate (cAMP) production. $\beta$-ARs are classified into $\beta 1, \beta 2$, and $\beta 3$ subtypes, in which, the former two have been much more explored [42,46]. Quite a lot of selective and nonselective $\beta$-AR agonists and antagonists (blockers) are available as drugs in the market to treat various cardiac and pulmonary disorders. In the brain, $\beta$-ARs are localized in the frontal cortex, striatum, thalamus, putamen, amygdala, cerebellum and hippocampus [48]. The density of $\beta$-ARs in brain is sensitive to brain pathophysiology. Notably, the density of $\beta$-ARs decrease with age [40]. Light microscopic autoradiography using $\left[{ }^{3} \mathrm{H}\right]$ dihydroaloprenolol (a selective $\beta$-blocker) with rat brain sections has shown a wide distribution of $\beta$-ARs in forebrain and cerebellum regions ( $B_{\max }=23 \mathrm{fmol} / \mathrm{mg}$ tissue) [103]. Similarly, $B_{\max }$ value of $18 \mathrm{fmol} / \mathrm{mg}$ protein was reported in pre-frontal cortex of subjects with Parkinson's disease $[48,104]$. By altering the $\mathrm{Ca}^{2+}$ levels through $N$-methyl- $D$-aspartate (NMDA) receptors in hippocampus, $\beta$-ARs modulate synaptic plasticity, including that needed for memory [44,45]. The blockade of $\beta$-ARs is associated with a small increased risk for Alzheimer's and Parkinson's disease $[43,105]$. In addition, abnormal function and densities of $\beta$-ARs have been reported in mood disorders and schizophrenia $[41,47,106]$.

Several radioligands, mostly based on $\beta$-blockers, were validated for imaging of $\beta$-ARs in the heart [50]. The majority of $\beta$-blockers possess a hydroxyl propylamine moiety in their structures that is vital for binding to $\beta$-ARs and this moiety was maintained in most of these radioligands. PET radiotracers have succeeded in imaging and quantifying myocardial and pulmonary $\beta$-ARs in human $[107,108]$, whereas, PET radiotracers for cerebral $\beta$-ARs have been more challenging. The clinical PET radiotracers for cardiac $\beta$-ARs have negative Log P values $(<-2)$, which is not suitable for imaging the brain. Several lipophilic and high to moderate affinity $\beta$-AR nonselective antagonists were explored as PET radiotracers to image $\beta$-ARs in the brain.

During the 1980s, propranolol, a $\beta$-blocker drug was labelled with C-11 (22, Figure 8) but was unsuitable as a PET ligand for $\beta$-ARs because of high nonspecific binding in vivo $[109,110]$. Subsequently, Berridge's group described the synthesis of two isomers $(R / S)$ of $\left[{ }^{18} \mathrm{~F}\right]$ fluorocarazolol 
(23, Figure 8) through reductive amination using $\left[{ }^{18} \mathrm{~F}\right]$ fluoroacetone and desisopropylcarazolol with 18.5-37 GBq/ $\mu \mathrm{mol}$ molar activity [111,112]. The radiotracer 23 has subnanomolar $K_{i}$ values for $\beta$-ARs ( $\beta 10.4 \mathrm{nM}, \beta 20.1 \mathrm{nM}$ ) and $\log \mathrm{P}_{7.4}$ value of 2.19. The same group used S-23 for PET imaging of the pig heart and lungs to validate the $\beta$-AR biding. In 1997, Waarde et al., employed S-23 to image $\beta$-ARs in the human brain and obtained positive results [113]. They observed specific binding (blocked with pindolol) of S-23 in $\beta$-AR rich areas, striatum and various cortical areas. However, the radiotracer was discontinued for further human studies as fluorocarazolol was positive for the Ames test i.e., mutagenic [114].<smiles>CC(C)[NH2+]CC(O)COc1cccc2ccccc12</smiles>

$\left[{ }^{11} \mathrm{C}\right]$ propranolol 22<smiles>CC(C[18F])NCC(O)COc1cccc2[nH]c3ccccc3c12</smiles>

$\left[{ }^{18} \mathrm{~F}\right]$ fluorocarazolol 23<smiles>CC(CF)NC[C@H](O)COc1cccc2ccccc12</smiles>

$\left[{ }^{18} \mathrm{~F}\right]$ fluoropropranolol 24<smiles>Cc1ccc(OCC(O)C[NH+](C)C)c2c1CCC2</smiles>

$\left[{ }^{11} \mathrm{C}\right] \mathrm{Cl} 11855125$

Figure 8. Early PET radiotracers for cerebral $\beta$-ARs.

Two research groups conducted biodistribution studies in rats using $\left[{ }^{18} \mathrm{~F}\right]$ fluoropropranolol (24) and [ $\left.{ }^{11} \mathrm{C}\right] \mathrm{ICI} 118,551$ (25) (Figure 8), which failed because of their nonspecific binding $[115,116]$. In 2001, Fazio's group described two isomers $(R / S)$ of C-11 labelled bisprolol $\left(\beta 1 K_{\mathrm{i}} 1.6 \mathrm{nM}, \beta 2 K_{\mathrm{i}} 100 \mathrm{nM}\right.$ and $\left.\log P_{7.4}=-0.2\right)(\mathbf{2 6}$, Figure 9) to image $\beta 1$-ARs in the brain [117]. The radiosynthesis of $\mathbf{2 6}$ was accomplished via reductive amination using $\left[{ }^{11} \mathrm{C}\right]$ acetone and desisopropyl bisprolol precursor with $129.5 \pm 37 \mathrm{GBq} / \mu \mathrm{mol}$ molar activity at the EOS. They observed little specific uptake of 26 in $\beta 1$-AR rich regions in the rat's brain and also high nonspecific uptake in the pituitary (1.8 $\pm 0.3 \mathrm{ID}$ at $30 \mathrm{~min})$, a region with high $\beta 2$-ARs levels. No further studies were reported using 26 to image $\beta$-ARs.

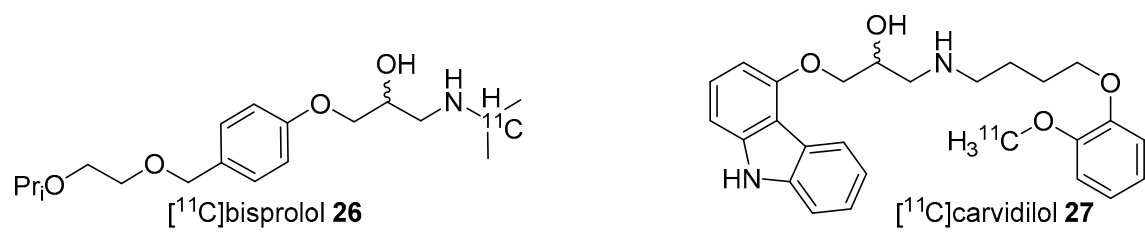

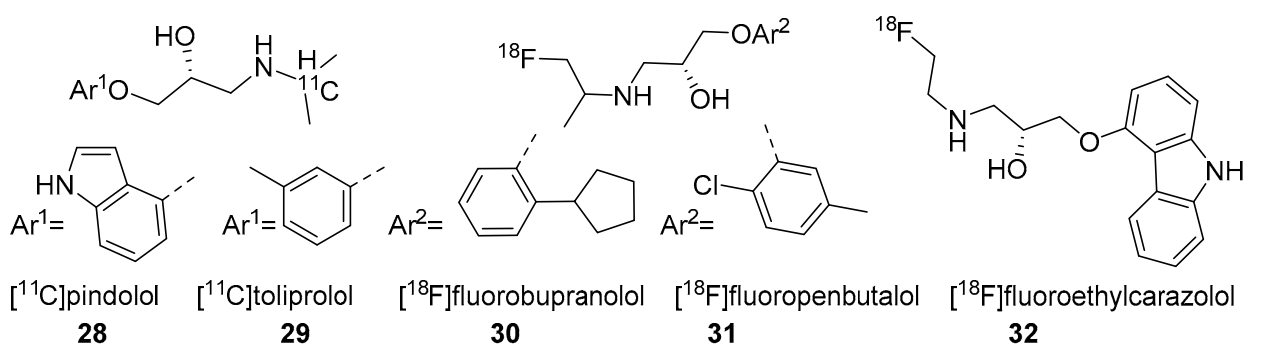

Figure 9. Radiotracers based on various $\beta$-AR blockers.

In 2002, Elsinga's group reported five different potent and lipophilic $\beta$-AR antagonists (carvedilol, pindolol, toliprolol, bupranolol, and penbutolol) as PET probes to image $\beta$-ARs in rat brain [118]. C-11 labelled carvedilol (27, Figure 9; molar activity 12.97-25.9 GBq/ $\mathrm{mol}$ ) was prepared through ${ }^{11} \mathrm{C}$-methylation using $\left[{ }^{11} \mathrm{C}\right] \mathrm{CH}_{3} \mathrm{I}$ and its respective $\mathrm{O}$-desmethyl precursor, whereas, $\left[{ }^{11} \mathrm{C}\right]$ pindolol $(\mathbf{2 8}$,

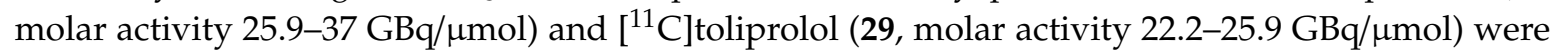
prepared via reductive amination using $\left[{ }^{11} \mathrm{C}\right]$ acetone and the respective desisopropyl precursors. The F-18 tracers of bupranolol (30, molar activity 11.1-18.5 GBq/ $\mu \mathrm{mol}$ ) and penbutolol (31, 22.2-99.9 GBq/ $\mu \mathrm{mol}$ ) were also prepared by means of reductive amination but using $\left[{ }^{18} \mathrm{~F}\right]$ fluoroacetone and the respective des-fluoro-isopropyl precursors. 
The five radiotracers had strong affinities (subnanomolar $K_{d}$ ) for $\beta 1$ and $\beta 2$-ARs. Although these radiotracers had sufficient affinity and lipophilicity for in vivo imaging, none showed good brain uptake. This group also evaluated S- $\left[{ }^{18} \mathrm{~F}\right]$ fluoroethylcarazolol $\left(32, \beta 1 K_{\mathrm{i}}=0.5 \mathrm{nM}, \beta 2 K_{\mathrm{i}}=0.4 \mathrm{nM}\right.$ and $\log P_{7.4}=1.94$ ) for in vivo imaging of $\beta$-ARs in rat brain [119]. The radiotracer 32 (Figure 9) was prepared via an epoxide ring-opening using $\left[{ }^{18} \mathrm{~F}\right]$ fluoroethylamine and the corresponding epoxide with $>10 \mathrm{GBq} / \mu \mathrm{mol}$ molar activity. The radiotracer accumulated in brain with uptake reflecting cerebral $\beta$-ARs binding. However, no further PET imaging studies were reported using 32 probably because of its analogous nature to 23 which was shown to be positive Ames test [114,120].

In 2008, Elsinga's and Vasdev's groups chose exaprolol ( $\left.\beta-\mathrm{AR} K_{\mathrm{d}}=9-9.5 \mathrm{nM}\right)$ and developed $S-\left[{ }^{11} \mathrm{C}\right]$ exaprolol (33) and $S-\left[{ }^{18} \mathrm{~F}\right]$ fluoroexaprolol (34), respectively, to image $\beta$-ARs with PET (Figure 10) $[120,121]$. Radiotracer 33 was prepared via reductive amination using $\left[{ }^{11} \mathrm{C}\right]$ acetone and desisopropylexaprolol precursor with $>10 \mathrm{GBq} / \mu \mathrm{mol}$ molar activity and the radiotracer $\mathbf{3 4}$ was prepared through a nucleophilic substitution reaction using $\left[{ }^{18} \mathrm{~F}\right]$ fluoride and a corresponding tosylate precursor followed by reductive hydrolysis, with $34.29 \mathrm{GBq} / \mu \mathrm{mol}$ molar activity. Regardless of good binding and kinetic properties, both these radiotracers showed high nonspecific uptake in the brain and were found to be inadequate for PET imaging of $\beta$-ARs.<smiles>[R]NC[C@H](O)COc1ccccc1C1CCCCC1</smiles>

$\left[{ }^{11} \mathrm{C}\right]$ exaprolol 33; $\mathrm{R}^{1}=\left[{ }^{11} \mathrm{C}\right] \mathrm{CH}\left(\mathrm{CH}_{3}\right)_{2}$ $\left[{ }^{18} \mathrm{~F}\right]$ fluoroexaprolol 34; $\mathrm{R}^{1}=\mathrm{CHCH}_{2}{ }^{18} \mathrm{FCH}_{3}$

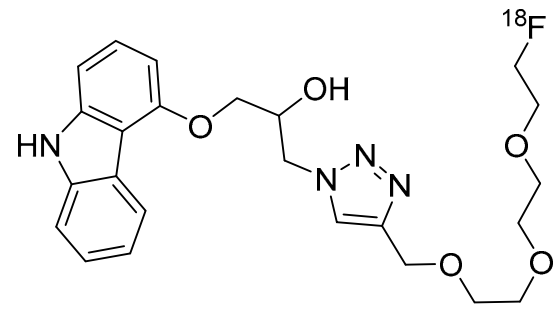

$\left[{ }^{18}\right.$ F]FPTC 35

Figure 10. Another set of latest $\beta$-AR PET radiotracers.

Again in 2014, Elsinga's group developed $\left[{ }^{18}\right.$ F]FPTC (35, Figure 10) for PET imaging of $\beta$-ARs in brain [122]. The radiotracer 35 is a derivative of carazolol, wherein, isopropylamine group of carazolol was replaced by a PEGylated triazole group. It was prepared through Huisgen's 1,3-dipolar cycloaddition (click reaction) using F-18 labelled PEGylated alkyne and the corresponding azide with $>120 \mathrm{GBq} / \mu \mathrm{mol}$ molar activity. Although 35 was shown to have appropriate $\log \mathrm{P}_{7.4}(2.48)$ and specific binding in in vitro assays, it could not visualize $\beta$-ARs in the brain, lung or heart using micro-PET.

Thus, the development of PET radiotracers for neuroimaging of $\beta$-ARs remains a challenge and as of now, there are no $\beta$-AR subtype specific PET radiotracers. Such radiotracers are important to expand our understanding of the role of $\beta$-ARs in aging and memory formation and also to assess their function in behavioral disorders. Future research, as suggested by Elsinga and Waarde [48], should consider modifying the imaging agents used for myocardial $\beta$-ARs rather than radiolabeling existing $\beta$-blocker drugs. Alterations should optimize $\log P_{7.4}(2-3)$, high affinity and selectivity to $\beta$-ARs and no substrate affinity for Pgp.

\section{Conclusions}

Over the past four decades, significant efforts have been made to develop CNS-ARs PET ligands for brain imaging. Despite these efforts, very few PET radiotracers are available to selectively image AR subtypes in the brain. The development of specific radiotracers is hindered mainly by the low receptor densities of each AR subclass within the brain, which requires further optimization processes for highly potent and BBB permeable ligands. Though challenging, AR subtype specific agonist/antagonist PET radiotracers are needed to ascertain AR's role in brain pathophysiology and for medication development. 
Funding: This research was funded by 'Tier 2 Research and Creative Works Strategic Investment Program Project of the University of Missouri (Internal Grant)' and the "Intramural Program of the National Institute on Alcohol Abuse and Alcoholism, grant number Y1AA-3009" and "The APC was funded by Y1AA-3009".

Conflicts of Interest: The authors declare no conflict of interest.

\section{References}

1. Scott, J.A. Positron Emission Tomography: Basic Science and Clinical Practice. Am. J. Roentgenol. 2004, 182, 418. [CrossRef]

2. Shukla, A.; Kumar, U. Positron emission tomography: An overview. J. Med. Phys. 2006, 31, 13-21. [CrossRef] [PubMed]

3. McCluskey, S.P.; Plisson, C.; Rabiner, E.A.; Howes, O. Advances in CNS PET: The state-of-the-art for new imaging targets for pathophysiology and drug development. Eur. J. Nucl. Med. Mol. Imaging 2020, 47, 451-489. [CrossRef]

4. Rankovic, Z. CNS Drug Design: Balancing Physicochemical Properties for Optimal Brain Exposure. J. Med. Chem. 2015, 58, 2584-2608. [CrossRef] [PubMed]

5. Adenot, M.; Lahana, R. Blood-Brain Barrier Permeation Models: Discriminating between Potential CNS and Non-CNS Drugs Including P-Glycoprotein Substrates. J. Chem. Inf. Comput. Sci. 2004, 44, 239-248. [CrossRef]

6. Agdeppa, E.D.; Spilker, M.E. A review of imaging agent development. AAPS J. 2009, 11, 286-299. [CrossRef]

7. Kumar, J.S.; Mann, J. PET Tracers for Serotonin Receptors and Their Applications. Cent. Nerv. Syst. Agents Med. Chem. 2014, 14, 96-112. [CrossRef]

8. Dunphy, M.P.S.; Lewis, J.S. Radiopharmaceuticals in preclinical and clinical development for monitoring of therapy with PET. J. Nucl. Med. 2009, 50, 106-122. [CrossRef]

9. Sneader, W. The discovery and synthesis of epinephrine. Drug News Perspect. 2001, 14, 491-494. [CrossRef]

10. Arthur, G. Epinephrine: A short history. Lancet Respir. Med. 2015, 3, 350-351. [CrossRef]

11. Schmidt, K.T.; Weinshenker, D. Adrenaline rush: The role of adrenergic receptors in stimulant-induced behaviors. Mol. Pharmacol. 2014, 85, 640-650. [CrossRef] [PubMed]

12. Eisenhofer, G.; Kopin, I.J.; Goldstein, D.S. Catecholamine metabolism: A contemporary view with implications for physiology and medicine. Pharmacol. Rev. 2004, 56, 331-349. [CrossRef] [PubMed]

13. Kirshner, N. Biosynthesis of adrenaline and noradrenaline. Pharmacol. Rev. 1959, 11, 350-357. [PubMed]

14. Flatmark, T. Catecholamine biosynthesis and physiological regulation in neuroendocrine cells. Acta Physiol. Scand. 2000, 168, 1-17. [CrossRef] [PubMed]

15. Ranjbar-Slamloo, Y.; Fazlali, Z. Dopamine and Noradrenaline in the Brain; Overlapping or Dissociate Functions? Front. Mol. Neurosci. 2020, 12,1-8. [CrossRef]

16. Strosberg, A.D. Structure, function, and regulation of adrenergic receptors. Protein Sci. 1993, 2, 1198-1209. [CrossRef]

17. Ahlquist, R.P. A study of the adrenotropic receptors. Am. J. Physiol. 1948, 153, 586-600. [CrossRef]

18. Philipp, M.; Hein, L. Adrenergic receptor knockout mice: Distinct functions of 9 receptor subtypes. Pharmacol. Ther. 2004, 101, 65-74. [CrossRef]

19. Paul, J.; Bylund, B.; Lefkowitz, J.; Eikenburg, C.; Ruffolo, R.; Langer, Z.; Minneman, P. International Union of Pharmacology X. Recommendation for Nomenclature of adrenoreceptors: Consensus update. Am. Soc. Pharmacol. Exp. Ther. 1995, 47, 267-270.

20. Day, H.E.W.; Campeau, S.; Watson, S.J.; Akil, H. Distribution of $\alpha(1 \mathrm{a})-, \alpha(1 \mathrm{~b})$ - and $\alpha(1 \mathrm{~d})$-adrenergic receptor mRNA in the rat brain and spinal cord. J. Chem. Neuroanat. 1997, 13, 115-139. [CrossRef]

21. Doze, V.A.; Handel, E.M.; Jensen, K.A.; Darsie, B.; Luger, E.J.; Haselton, J.R.; Talbot, J.N.; Rorabaugh, B.R. $\alpha 1 \mathrm{~A}-$ and $\alpha 1 \mathrm{~B}$-adrenergic receptors differentially modulate antidepressant-like behavior in the mouse. Brain Res. 2009, 1285, 148-157. [CrossRef] [PubMed]

22. Leslie, A. Characterization of a1-Adrenergic Receptor Subtypes in Rat Brain: A Reevaluation of [3H] WB41 04 and [3H] Prazosin Binding. Pharmacol. Exet. Am. Chem. Sciety Pharmacol. Experiemntal Ther. 1986, 29, 321-330.

23. Reader, T.A.; Brière, R.; Grondin, L. Alpha-1 and alpha-2 adrenoceptor binding in cerebral cortex: Competition studies with [3H]prazosin and [3H]idazoxan. J. Neural Transm. 1987, 68, 79-95. [CrossRef] [PubMed] 
24. Drouin, C.; Darracq, L.; Trovero, F.; Blanc, G.; Glowinski, J.; Cotecchia, S.; Tassin, J.P. $\alpha 1 b-A d r e n e r g i c$ Receptors Control Locomotor and Rewarding Effects of Psychostimulants and Opiates. J. Neurosci. 2002, 22, 2873-2884. [CrossRef]

25. Zuscik, M.J.; Sands, S.; Ross, S.A.; Waugh, D.J.J.; Gaivin, R.J.; Morilak, D.; Perez, D.M. Overexpression of the $\alpha(1 \mathrm{~B})$-adrenergic receptor causes apoptotic neurodegeneration: Multiple system atrophy. Nat. Med. 2000, 6, 1388-1394. [CrossRef]

26. Hayashi, R.; Ohmori, E.; Isogaya, M.; Moriwaki, M.; Kumagai, H. Design and synthesis of selective $\alpha 1 B$ adrenoceptor antagonists. Bioorg. Med. Chem. Lett. 2006, 16, 4045-4047. [CrossRef]

27. Spreng, M.; Cotecchia, S.; Schenk, F. A behavioral study of alpha-1b adrenergic receptor knockout mice: Increased reaction to novelty and selectively reduced learning capacities. Neurobiol. Learn. Mem. 2001, 75, 214-229. [CrossRef]

28. Sadalge, A.; Coughlin, L.; Fu, H.; Wang, B.; Valladares, O.; Valentino, R.; Blendy, J.A. A1D Adrenoceptor Signaling Is Required for Stimulus Induced Locomotor Activity. Mol. Psychiatry 2003, 8, 664-672. [CrossRef]

29. Buckner, S.A.; Milicic, I.; Daza, A.; Lynch, J.J.; Kolasa, T.; Nakane, M.; Sullivan, J.P.; Brioni, J.D. A-315456: A selective $\alpha 1 \mathrm{D}$-adrenoceptor antagonist with minimal dopamine D2 and 5-HT1A receptor affinity. Eur. J. Pharmacol. 2001, 433, 123-127. [CrossRef]

30. Saunders, C.; Limbird, L.E. Localization and trafficking of $\alpha 2$-adrenergic receptor subtypes in cells and tissues. Pharmacol. Ther. 1999, 84, 193-205. [CrossRef]

31. Sastre, M.; García-Sevilla, J.A. $\alpha$ 2-Adrenoceptor Subtypes Identified by [3H]RX821002 Binding in the Human Brain: The Agonist Guanoxabenz Does Not Discriminate Different Forms of the Predominant $\alpha 2$ A Subtype. J. Neurochem. 1994, 63, 1077-1085. [CrossRef] [PubMed]

32. Gilsbach, R.; Hein, L. Are the pharmacology and physiology of $\alpha$ 2adrenoceptors determined by $\alpha$ 2-heteroreceptors and autoreceptors respectively? Br. J. Pharmacol. 2012, 165, 90-102. [CrossRef] [PubMed]

33. Wasilewska, A.; Sączewski, F.; Hudson, A.L.; Ferdousi, M.; Scheinin, M.; Laurila, J.M.; Rybczyńska, A.; Boblewski, K.; Lehmann, A. Fluorinated analogues of marsanidine, a highly $\alpha 2$-AR/imidazoline I1 binding site-selective hypotensive agent. Synthesis and biological activities. Eur. J. Med. Chem. 2014, 87, 386-397. [CrossRef] [PubMed]

34. Krzyczmonik, A.; Keller, T.; López-Picón, F.R.; Forsback, S.; Kirjavainen, A.K.; Takkinen, J.S.; Wasilewska, A.; Scheinin, M.; Haaparanta-Solin, M.; Saczewski, F.; et al. Radiosynthesis and Preclinical Evaluation of an

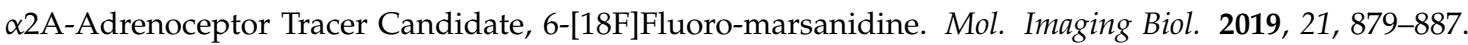
[CrossRef] [PubMed]

35. Prabhakaran, J.; Majo, V.J.; Milak, M.S.; Mali, P.; Savenkova, L.; Mann, J.J.; Parsey, R.V.; Kumar, J.S.D. Synthesis and in vivo evaluation of [11C]MPTQ: A potential PET tracer for alpha2A-adrenergic receptors. Bioorg. Med. Chem. Lett. 2010, 20, 3654-3657. [CrossRef]

36. Arponen, E.; Helin, S.; Marjamäki, P.; Grönroos, T.; Holm, P.; Löyttyniemi, E.; Någren, K.; Scheinin, M.; Haaparanta-Solin, M.; Sallinen, J.; et al. A PET tracer for brain $\alpha 2$ C adrenoceptors, 11C-ORM-13070: Radiosynthesis and preclinical evaluation in rats and knockout mice. J. Nucl. Med. 2014, 55, 1171-1177. [CrossRef]

37. Kawamura, K.; Akiyama, M.; Yui, J.; Yamasaki, T.; Hatori, A.; Kumata, K.; Wakizaka, H.; Takei, M.; Nengaki, N.; Yanamoto, K.; et al. In vivo evaluation of limiting brain penetration of probes for $\alpha 2 \mathrm{C}$-adrenoceptor using small-animal positron emission tomography. ACS Chem. Neurosci. 2010, 1, 520-528. [CrossRef]

38. Sallinen, J.; Höglund, I.; Engström, M.; Lehtimäki, J.; Virtanen, R.; Sirviö, J.; Wurster, S.; Savola, J.M.; Haapalinna, A. Pharmacological characterization and CNS effects of a novel highly selective $\alpha 2 \mathrm{C}$-adrenoceptor antagonist JP-1302. Br. J. Pharmacol. 2007, 150, 391-402. [CrossRef]

39. Luoto, P.; Suilamo, S.; Oikonen, V.; Arponen, E.; Helin, S.; Herttuainen, J.; Hietamäki, J.; Holopainen, A.; Kailajärvi, M.; Peltonen, J.M.; et al. 11C-ORM-13070, a novel PET ligand for brain $\alpha 2$ C-adrenoceptors: Radiometabolism, plasma pharmacokinetics, whole-body distribution and radiation dosimetry in healthy men. Eur. J. Nucl. Med. Mol. Imaging 2014, 41, 1947-1956. [CrossRef]

40. Sscarpace, P.J.; Abrass, I.B. Alpha- and beta-adrenergic receptor function in the brain during senescence. Neurobiol. Aging 1988, 9, 53-58. [CrossRef]

41. Pandey, S.C.; Ren, X.; Sagen, J.; Pandey, G.N. $\beta$-Adrenergic receptor subtypes in stress-induced behavioral depression. Pharmacol. Biochem. Behav. 1995, 51, 339-344. [CrossRef]

42. Wallukat, G. The $\beta$-adrenergic receptors. Herz 2002, 27, 683-690. [CrossRef] [PubMed] 
43. $\mathrm{Lu}^{\prime} \mathrm{O}^{\prime} \mathrm{Ng}$, K.V.Q.; Nguyen, L.T.H. The role of beta-adrenergic receptor blockers in Alzheimer's disease: Potential genetic and cellular signaling mechanisms. Am. J. Alzheimers. Dis. Demen. 2013, 28, 427-439. [CrossRef] [PubMed]

44. O'Dell, T.J.; Connor, S.A.; Guglietta, R.; Nguyen, P.V. $\beta$-Adrenergic receptor signaling and modulation of long-term potentiation in the mammalian hippocampus. Learn. Mem. 2015, 22, 461-471. [CrossRef]

45. Gelinas, J.; Nguyen, P. Neuromodulation of Hippocampal Synaptic Plasticity, Learning, and Memory by Noradrenaline. Cent. Nerv. Syst. Agents Med. Chem. 2008, 7, 17-33. [CrossRef]

46. Wachter, S.B.; Gilbert, E.M. Beta-adrenergic receptors, from their discovery and characterization through their manipulation to beneficial clinical application. Cardiology 2012, 122, 104-112. [CrossRef]

47. Joyce, J.N.; Lexow, N.; Kim, S.J.; Artymyshyn, R.; Senzon, S.; Lawerence, D.; Cassanova, M.F.; Kleinman, J.E.; Bird, E.D.; Winokur, A. Distribution of beta-adrenergic receptor subtypes in human post-mortem brain: Alterations in limbic regions of schizophrenics. Synapse 1992, 10, 228-246. [CrossRef]

48. Waarde, A.; Vaalburg, W.; Doze, P.; Bosker, F.; Elsinga, P. PET Imaging of Beta-Adrenoceptors in Human Brain: A Realistic Goal or a Mirage? Curr. Pharm. Des. 2005, 10, 1519-1536. [CrossRef]

49. Pike, V.W.; Law, M.P.; Osman, S.; Davenport, R.J.; Rimoldi, O.; Giardinà, D.; Camici, P.G. Selection, design and evaluation of new radioligands for PET studies of cardiac adrenoceptors. Pharm. Acta Helv. 2000, 74, 191-200. [CrossRef]

50. Chen, X.; Werner, R.A.; Javadi, M.S.; Maya, Y.; Decker, M.; Lapa, C.; Herrmann, K.; Higuchi, T. Radionuclide imaging of neurohormonal system of the heart. Theranostics 2015, 5, 545-558. [CrossRef]

51. Logan, J.; Wang, G.J.; Telang, F.; Fowler, J.S.; Alexoff, D.; Zabroski, J.; Jayne, M.; Hubbard, B.; King, P.; Carter, P.; et al. Imaging the norepinephrine transporter in humans with (S,S)-[11C]O-methyl reboxetine and PET: Problems and progress. Nucl. Med. Biol. 2007, 34, 667-679. [CrossRef] [PubMed]

52. Chen, X.; Kudo, T.; Lapa, C.; Buck, A.; Higuchi, T. Recent advances in radiotracers targeting norepinephrine transporter: Structural development and radiolabeling improvements. J. Neural Transm. 2020, 127, 851-873. [CrossRef] [PubMed]

53. Zeng, F.; Mun, J.; Jarkas, N.; Stehouwer, J.S.; Voll, R.J.; Tamagnan, G.D.; Howell, L.; Votaw, J.R.; Kilts, C.D.; Nemeroff, C.B.; et al. Synthesis, Radiosynthesis, and Biological Evaluation of Carbon-11 and Fluorine-18 Labeled Reboxetine Analogs: Potential Positron Emission Tomography Radioligands for in Vivo Imaging of the Norepinephrine Transporter. J. Med. Chem. 2009, 52, 62-73. [CrossRef] [PubMed]

54. Moriguchi, S.; Kimura, Y.; Ichise, M.; Arakawa, R.; Takano, H.; Seki, C.; Ikoma, Y.; Takahata, K.; Nagashima, T.; Yamada, M.; et al. PET quantification of the norepinephrine transporter in human brain with (S,S)-18F-FMeNER-D2. J. Nucl. Med. 2017, 58, 1140-1145. [CrossRef]

55. Narayanaswami, V.; Drake, L.R.; Brooks, A.F.; Meyer, J.H.; Houle, S.; Kilbourn, M.R.; Scott, P.J.H.; Vasdev, N. Classics in Neuroimaging: Development of PET Tracers for Imaging Monoamine Oxidases. ACS Chem. Neurosci. 2019, 10, 1867-1871. [CrossRef]

56. Fowler, J.S.; Logan, J.; Shumay, E.; Alia-Klein, N.; Wang, G.J.; Volkow, N.D. Monoamine oxidase: Radiotracer chemistry and human studies. J. Label. Compd. Radiopharm. 2015, 58, 51-64. [CrossRef]

57. Narayanaswami, V.; Dahl, K.; Bernard-Gauthier, V.; Josephson, L.; Cumming, P.; Vasdev, N. Emerging PET Radiotracers and Targets for Imaging of Neuroinflammation in Neurodegenerative Diseases: Outlook Beyond TSPO. Mol. Imaging 2018, 17, 1-25. [CrossRef]

58. Piascik, M.T.; Perez, D.M. $\alpha 1$-Adrenergic receptors: New insights and directions. J. Pharmacol. Exp. Ther. 2001, 298, 403-410.

59. Graham, R.M.; Perez, D.M.; Hwa, J.; Piascik, M.T. $\alpha 1$-Adrenergic Receptor Subtypes. Circ. Res. 1996, 78, 737-749. [CrossRef]

60. Chen, Z.J.; Minneman, K.P. Recent progress in $\alpha 1$-adrenergic receptor research. Acta Pharmacol. Sin. 2005, 26, 1281-1287. [CrossRef]

61. O'Connell, T.D.; Jensen, B.C.; Baker, A.J.; Simpson, P.C. Cardiac alpha1-adrenergic receptors: Novel aspects of expression, signaling mechanisms, physiologic function, and clinical importance. Pharmacol. Rev. 2014, 66, 308-333. [CrossRef] [PubMed]

62. Jensen, B.C.; O'Connell, T.D.; Simpson, P.C. Alpha-1-adrenergic receptors in heart failure: The adaptive arm of the cardiac response to chronic catecholamine stimulation. J. Cardiovasc. Pharmacol. 2014, 63, 291-301. [CrossRef] [PubMed] 
63. Morrow, A.L.; Creese, I. Characterization of Alpha-1-Adrenergic Receptor Subtypes in Rat-BrainA Reevaluation of [H-3] Wb4104 and [H-3] Prazosin Binding. Mol. Pharmacol. 1986, 29, 321-330. [PubMed]

64. Romero-grimaldi, C.; Moreno-lo, B. Age-Dependent Effect of Nitric Oxide on Subventricular Zone and Olfactory Bulb. J. Comp. Neurol. 2008, 346, 339-346. [CrossRef] [PubMed]

65. Campeau, S.; Nyhuis, T.J.; Kryskow, E.M.; Masini, C.V.; Babb, J.A.; Sasse, S.K.; Greenwood, B.N.; Fleshner, M.; Day, H.E.W. Stress rapidly increases alpha 1d adrenergic receptor mRNA in the rat dentate gyrus. Brain Res. 2010, 1323, 109-118. [CrossRef]

66. Szot, P.; White, S.S.; Greenup, J.L.; Leverenz, J.B.; Peskind, E.R.; Raskind, M.A. Changes in Adrenoreceptors in The Prefrontal Cortex Of Subjects With Dementia: Evidence Of Compensatory Changes. Neuroscience 2007, 146, 471-480. [CrossRef]

67. Perez, D.M.; Doze, V.A. Cardiac and neuroprotection regulated by alpha1-AR subtypes. J. Recept Signal. Transduct Res. 2011, 31, 98-110. [CrossRef]

68. Sica, D. Alpha-1 adrenergic Blockers: Current Usage Considerations. J. Clin. Hypertens. 2005, 7, 757-762. [CrossRef]

69. Miriam, H.; Hein, L. $\alpha 1$-Adrenozeptor-Antagonisten. Bei BPS und Hypertonie. Pharm. Unserer Zeit 2008, 37, 290-295. [CrossRef]

70. Law, M.P.; Osman, S.; Pike, V.W.; Davenport, R.J.; Cunningham, V.J.; Rimoldi, O.; Rhodes, C.G.; Giardinà, D.; Camici, P.G. Evaluation of [11C]GB67, a novel radioligand for imaging myocardial ( $\alpha 1$-adrenoceptors with positron emission tomography. Eur. J. Nucl. Med. 2000, 27, 7-17. [CrossRef]

71. Nyberg, S.; Eriksson, B.; Oxenstierna, G.; Halldin, C.; Farde, L. Suggested minimal effective dose of risperidone based on PET-measured D2 and 5-HT(2A) receptor occupancy in schizophrenic patients. Am. J. Psychiatry 1999, 156, 869-875. [CrossRef] [PubMed]

72. Nyberg, S.; Olsson, H.; Nilsson, U.; Maehlum, E.; Halldin, C.; Farde, L. Low striatal and extra-striatal D2 receptor occupancy during treatment with the atypical antipsychotic sertindole. Psychopharmacology (Berl.) 2002, 162, 37-41. [CrossRef]

73. Balle, T.; Perregaard, J.; Ramirez, M.T.; Larsen, A.K.; Søby, K.K.; Liljefors, T.; Andersen, K. Synthesis and structure-affinity relationship investigations of 5-heteroaryl-substituted analogues of the antipsychotic sertindole. A new class of highly selective $\alpha 1$ adrenoceptor antagonists. J. Med. Chem. 2003, 46, 265-283. [CrossRef] [PubMed]

74. Balle, T.; Halldin, C.; Andersen, L.; Alifrangis, L.H.; Badolo, L.; Jensen, K.G.; Chou, Y.W.; Andersen, K.; Perregaard, J.; Farde, L. New $\alpha 1$-adrenoceptor antagonists derived from the antipsychotic sertindole-Carbon-11 labelling and pet examination of brain uptake in the cynomolgus monkey. Nucl. Med. Biol. 2004, 31, 327-336. [CrossRef] [PubMed]

75. Airaksinen, A.J.; Finnema, S.J.; Balle, T.; Varnäs, K.; Bang-Andersen, B.; Gulyás, B.; Farde, L.; Halldin, C. Radiosynthesis and evaluation of new $\alpha 1$-adrenoceptor antagonists as PET radioligands for brain imaging. Nucl. Med. Biol. 2013, 40,747-754. [CrossRef]

76. Risgaard, R.; Ettrup, A.; Balle, T.; Dyssegaard, A.; Hansen, H.D.; Lehel, S.; Madsen, J.; Pedersen, H.; Püschl, A.; Badolo, L.; et al. Radiolabelling and PET brain imaging of the $\alpha 1$-adrenoceptor antagonist Lu AE43936. Nucl. Med. Biol. 2013, 40, 135-140. [CrossRef]

77. Jorgensen, M.; Jorgensen, P.N.; Christoffersen, C.T.; Jensen, K.G.; Balle, T.; Bang-Andersen, B. Discovery of novel $\alpha 1$-adrenoceptor ligands based on the antipsychotic sertindole suitable for labeling as PET ligands. Bioorg. Med. Chem. 2013, 21, 196-204. [CrossRef]

78. Bøgesø, K.P.; Arnt, J.; Hyttel, J.; Pedersen, H.; Liljefors, T. Octoclothepin Enantiomers. A Reinvestigation of Their Biochemical and Pharmacological Activity in Relation to a New Receptor-Interaction Model for Dopamine D-2 Receptor Antagonists. J. Med. Chem. 1991, 34, 2023-2030. [CrossRef]

79. Liow, J.S.; Lu, S.; McCarron, J.A.; Hong, J.; Musachio, J.L.; Pike, V.W.; Innis, R.B.; Zoghbi, S.S. Effect of a P-Glycoprotein Inhibitor, Cyclosporin A, on the Disposition in Rodent Brain and Blood of the 5-HT1A Receptor Radioligand, [11C](R)-(-)-RWAY. Synapse 2007, 61, 96-105. [CrossRef]

80. Roberts, L.R.; Bryans, J.; Conlon, K.; McMurray, G.; Stobie, A.; Whitlock, G.A. Novel 2-imidazoles as potent, selective and CNS penetrant $\alpha 1 \mathrm{~A}$ adrenoceptor partial agonists. Bioorg. Med. Chem. Lett. 2008, 18, 6437-6440. [CrossRef]

81. Whitlock, G.A.; Brennan, P.E.; Roberts, L.R.; Stobie, A. Potent and selective $\alpha 1$ A adrenoceptor partial agonists-Novel imidazole frameworks. Bioorg. Med. Chem. Lett. 2009, 19, 3118-3121. [CrossRef] [PubMed] 
82. Bücheler, M.M.; Hadamek, K.; Hein, L. Two $\alpha 2$-adrenergic receptor subtypes, $\alpha 2 \mathrm{~A}$ and $\alpha 2 \mathrm{C}$, inhibit transmitter release in the brain of gene-targeted mice. Neuroscience 2002, 109, 819-826. [CrossRef]

83. Nguyen, V.; Tiemann, D.; Park, E.; Salehi, A. Alpha-2 Agonists. Anesthesiol. Clin. 2017, 35, 233-245. [CrossRef] [PubMed]

84. Khan, Z.P.; Ferguson, C.N.; Jones, R.M. Alpha-2 and imidazoline receptor agonists. Their pharmacology and therapeutic role. Anaesthesia 1999, 54, 146-165. [CrossRef]

85. Paciorek, P.M.; Pierce, V.; Shepperson, N.B.; Waterfall, J.F. An investigation into the selectivity of a novel series of benzoquinolizines for $\alpha$-adrenoceptors in vivo. Br. J. Pharmacol. 1984, 82, 127-134. [CrossRef]

86. Pettibone, D.J.; Flagg, S.D.; Totarol, J.A.; Clineschmidt, B.V.; Huff, J.R.; Young, S.D.; Chen, R. [3H]L-657, 743 (MK-912): A new, high affinity, selective radioligand for brain $\alpha-2$ adrenoceptors. Life Sci. 1989, 44, 459-467. [CrossRef]

87. Pleus, R.C.; Shiue, C.Y.; Shiue, G.G.; Rysavy, J.A.; Huang, H.; Cornish, K.G.; Sunderland, J.J.; Bylund, D.B. Synthesis and biodistribution of the alpha 2-adrenergic receptor antagonist (11C)WY26703. Use as a radioligand for positron emission tomography. Receptor 1992, 2, 241-252.

88. Shiue, C.Y.; Pleus, R.C.; Shiue, G.G.; Rysavy, J.A.; Sunderland, J.J.; Cornish, K.G.; Young, S.D.; Bylund, D.B. Synthesis and biological evaluation of [11C]MK-912 as an $\alpha 2$ - adrenergic receptor radioligand for PET studies. Nucl. Med. Biol. 1998, 25, 127-133. [CrossRef]

89. BK, F.D.; Terrazzino, S.; Tavitian, B.; Hinnen, F.; Vaufrey, F.; Crouzel, C. XIIth international symposium on radiopharmaceutical chemistry: Abstracts and programme. J. Label. Compd. Radiopharm. 1997, 40, 1-72. [CrossRef]

90. Hume, S.P.; Hirani, E.; Opacka-Juffry, J.; Osman, S.; Myers, R.; Gunn, R.N.; McCarron, J.A.; Clark, R.D.; Melichar, J.; Nutt, D.J.; et al. Evaluation of [O-methyl-11C]RS.15385-197 as a positron emission tomography radioligand for central $\alpha 2$-adrenoceptors. Eur. J. Nucl. Med. 2000, 27, 475-484. [CrossRef]

91. Roeda, D.; Sipil, H.T.; Bramoull, Y.; Enas, J.D.; Vaufrey, F.; Doll, F.; Crouzel, C. Synthesis of [11C]atipamezole, a potential PET ligand for the $\alpha 2$-adrenergic receptor in the brain. J. Label. Compd. Radiopharm. 2002, 45, 37-47. [CrossRef]

92. Marthi, K.; Bender, D.; Watanabe, H.; Smith, D.F. PET evaluation of a tetracyclic, atypical antidepressant, [N-methyl-11C]mianserin, in the living porcine brain. Nucl. Med. Biol. 2002, 29, 317-319. [CrossRef]

93. Marthi, K.; Bender, D.; Gjedde, A.; Smith, D.F. [11C]Mirtazapine for PET neuroimaging: Radiosynthesis and initial evaluation in the living porcine brain. Eur. Neuropsychopharmacol. 2002, 12, 427-432. [CrossRef]

94. Marthi, K.; Jakobsen, S.; Bender, D.; Hansen, S.B.; Smith, S.B.; Hermansen, F.; Rosenberg, R.; Smith, D.F. [N-methyl-11C]Mirtazapine for positron emission tomography neuroimaging of antidepressant actions in humans. Psychopharmacology (Berl.) 2004, 174, 260-265. [CrossRef] [PubMed]

95. Smith, D.F.; Stork, B.S.; Wegener, G.; Ashkanian, M.; Jakobsen, S.; Bender, D.; Audrain, H.; Vase, K.H.; Hansen, S.B.; Videbech, P.; et al. [11C]mirtazapine binding in depressed antidepressant nonresponders studied by PET neuroimaging. Psychopharmacology (Berl.) 2009, 206, 133-140. [CrossRef] [PubMed]

96. Van der Mey, M.; Windhorst, A.D.; Klok, R.P.; Herscheid, J.D.M.; Kennis, L.E.; Bischoff, F.; Bakker, M.; Langlois, X.; Heylen, L.; Jurzak, M.; et al. Synthesis and biodistribution of [11C]R107474, a new radiolabeled $\alpha 2$-adrenoceptor antagonist. Bioorg. Med. Chem. 2006, 14, 4526-4534. [CrossRef]

97. Jakobsen, S.; Pedersen, K.; Smith, D.F.; Jensen, S.B.; Munk, O.L.; Cumming, P. Detection of a 2 -Adrenergic Receptors in Brain of Living Pig with 11 C-Yohimbine. J. Nucl. Med. 2006, 47, 2008-2015.

98. Nahimi, A.; Jakobsen, S.; Munk, O.L.; Vang, K.; Phan, J.A.; Rodell, A.; Gjedde, A. Mapping $\alpha 2$ adrenoceptors of the human brain with11C-yohimbine. J. Nucl. Med. 2015, 56, 392-398. [CrossRef]

99. Andrés, J.I.; Alcázar, J.; Alonso, J.M.; Alvarez, R.M.; Bakker, M.H.; Biesmans, I.; Cid, J.M.; De Lucas, A.I.; Fernández, J.; Font, L.M.; et al. Discovery of a new series of centrally active tricyclic isoxazoles combining serotonin (5-HT) reuptake inhibition with $\alpha 2$ - adrenoceptor blocking activity. J. Med. Chem. 2005, 48, 2054-2071. [CrossRef]

100. Sa,czewski, F.; Kornicka, A.; Rybczyńska, A.; Hudson, A.L.; Shu, S.M.; Gdaniec, M.; Boblewski, K.; Lehmann, A. 1-[(imidazolidin-2-yl)imino]indazole. Highly $\alpha 2 / \mathrm{I} 1$ selective agonist: Synthesis, X-ray structure, and biological activity. J. Med. Chem. 2008, 51, 3599-3608. [CrossRef]

101. Hagihara, K.; Kashima, H.; Iida, K.; Enokizono, J.; Uchida, S.I.; Nonaka, H.; Kurokawa, M.; Shimada, J. Novel 4-(6,7-dimethoxy-1,2,3,4-tetrahydroisoquinolin-2-yl)methylbenzofuran derivatives as selective «2C-adrenergic receptor antagonists. Bioorg. Med. Chem. Lett. 2007, 17, 1616-1621. [CrossRef] [PubMed] 
102. Finnema, S.J.; Hughes, Z.A.; Haaparanta-Solin, M.; Stepanov, V.; Nakao, R.; Varnäs, K.; Varrone, A.; Arponen, E.; Marjamäki, P.; Pohjanoksa, K.; et al. Amphetamine decreases $\alpha 2$-adrenoceptor binding of [11C]ORM-13070: A PET study in the primate brain. Int. J. Neuropsychopharmacol. 2015, 18, 1-10. [CrossRef] [PubMed]

103. Palacios, J.M.; Kuhar, M.J. Beta adrenergic receptor localization in rat brain by light microscopic autoradiography. Neurochem. Int. 1982, 4, 473-490. [CrossRef]

104. Cash, R.; Ruberg, M.; Raisman, R.; Agid, Y. Adrenergic receptors in Parkinson's disease. Brain Res. 1984, 322, 269-275. [CrossRef]

105. Hopfner, F.; Höglinger, G.U.; Kuhlenbäumer, G.; Pottegård, A.; Wod, M.; Christensen, K.; Tanner, C.M.; Deuschl, G. $\beta$-adrenoreceptors and the risk of Parkinson's disease. Lancet Neurol. 2020, 19, 247-254. [CrossRef]

106. Klimek, V.; Rajkowska, G.; Luker, S.N.; Dilley, G.; Meltzer, H.Y.; Overholser, J.C.; Stockmeier, C.A.; Ordway, G.A. Brain noradrenergic receptors in major depression and schizophrenia. Neuropsychopharmacology 1999, 21, 69-81. [CrossRef]

107. Ueki, J.; Rhodes, C.G.; Hughes, J.M.; De Silva, R.; Lefroy, D.C.; Ind, P.W.; Qing, F.; Brady, F.; Luthra, S.K.; Steel, C.J. In vivo quantification of pulmonary B-adrenoceptor density in humans with (S)-[11C]CGP-12177 and PET. Am. Physiol. Soc. 1993, 75, 559-565. [CrossRef] [PubMed]

108. Elsinga, P.H.; Doze, P.; Van Waarde, A.; Pieterman, R.M.; Blanksma, P.K.; Willemsen, A.T.M.; Vaalburg, W. Imaging of $\beta$-adrenoceptors in the human thorax using (S)-[11C]CGP12388 and positron emission tomography. Eur. J. Pharmacol. 2001, 433, 173-176. [CrossRef]

109. Berger, G.; Maziere, M.; Prenant, C.; Sastre, J.; Syrota, A.; Comar, D. Synthesis of 11 C propranolol. J. Radioanal. Chem. 1982, 74, 301-306. [CrossRef]

110. Antoni, G.; Ulin, J.; Långström, B. Synthesis of the 11C-labelled $\beta$-adrenergic receptor ligands atenolol, metoprolol and propranolol. Int. J. Radiat. Appl. Instrum. Part A 1989, 40, 561-564. [CrossRef]

111. Berridge, M.S.; Nelson, A.D.; Zheng, L.; Leisure, G.P.; Miraldi, F. Specific beta-adrenergic receptor binding of carazolol measured with PET. J. Nucl. Med. 1994, 35, 1665-1676.

112. Zheng, L.; Berridge, M.S.; Ernsberger, P. Synthesis, Binding Properties, and 18F Labeling of Fluorocarazolol, a High-Affinity $\beta$-Adrenergic Receptor Antagonist. J. Med. Chem. 1994, 37, 3219-3230. [CrossRef] [PubMed]

113. Doze, P.; Van Waarde, A.; Elsinga, P.H.; Van-Loenen Weemaes, A.M.A.; Willemsen, A.T.M.; Vaalburg, W. Validation of S-1'-[18F]fluorocarazolol for in vivo imaging and quantification of cerebral $\beta$-adrenoceptors. Eur. J. Pharmacol. 1998, 353, 215-226. [CrossRef]

114. Doze, P.; Elsinga, P.H.; De Vries, E.F.J.; Van Waarde, A.; Vaalburg, W. Mutagenic activity of a fluorinated analog of the beta-adrenoceptor ligand carazolol in the Ames test. Nucl. Med. Biol. 2000, 27, 315-319. [CrossRef]

115. Tewson, T.J.; Stekhova, S.; Kinsey, B.; Chen, L.; Wiens, L.; Barber, R. Synthesis and biodistribution of R- and S-isomers of [18F]- fluoropropranolol, a lipophilic ligand for the $\beta$-adrenergic receptor. Nucl. Med. Biol. 1999, 26, 891-896. [CrossRef]

116. Moresco, R.M.; Matarrese, M.; Soloviev, D.; Simonelli, P.; Rigamonti, M.; Gobbo, C.; Todde, S.; Carpinelli, A.; Galli Kienle, M.; Fazio, F. Synthesis and in vivo evaluation of [11C]ICI 118551 as a putative subtype selective $\beta 2$-adrenergic radioligand. Int. J. Pharm. 2000, 204, 101-109. [CrossRef]

117. Soloviev, D.V.; Matarrese, M.; Moresco, R.M.; Todde, S.; Bonasera, T.A.; Sudati, F.; Simonelli, P.; Magni, F.; Colombo, D.; Carpinelli, A.; et al. Asymmetric synthesis and preliminary evaluation of $(R)$ - and (S)-[11C]bisoprolol, a putative $\beta 1$-selective adrenoceptor radioligand. Neurochem. Int. 2001, 38, 169-180. [CrossRef]

118. Doze, P.; Elsinga, P.H.; Maas, B.; Van Waarde, A.; Wegman, T.; Vaalburg, W. Synthesis and evaluation of radiolabeled antagonists for imaging of $\beta$-adrenoceptors in the brain with PET. Neurochem. Int. 2002, 40, 145-155. [CrossRef]

119. Doze, P.; Van Waarde, A.; Tewson, T.J.; Vaalburg, W.; Elsinga, P.H. Synthesis and evaluation of (S)-[18F]-fluoroethylcarazolol for in vivo $\beta$-adrenoceptor imaging in the brain. Neurochem. Int. 2002, 41, 17-27. [CrossRef]

120. van Waarde, A.; Doorduin, J.; de Jong, J.R.; Dierckx, R.A.; Elsinga, P.H. Synthesis and preliminary evaluation of (S)-[11C]-exaprolol, a novel $\beta$-adrenoceptor ligand for PET. Neurochem. Int. 2008, 52, 729-733. [CrossRef] 
121. Stephenson, K.A.; van Oosten, E.M.; Wilson, A.A.; Meyer, J.H.; Houle, S.; Vasdev, N. Synthesis and preliminary evaluation of [18F]-fluoro-(2S)-Exaprolol for imaging cerebral $\beta$-adrenergic receptors with PET. Neurochem. Int. 2008, 53, 173-179. [CrossRef] [PubMed]

122. Mirfeizi, L.; Rybczynska, A.A.; van Waarde, A.; Campbell-Verduyn, L.; Feringa, B.L.; Dierckx, R.A.J.O.; Elsinga, P.H. [18F]-(fluoromethoxy)ethoxy)methyl)-1H-1,2,3-triazol-1-yl)propan-2-ol ([18F FPTC) a novel PET-ligand for cerebral beta-adrenoceptors. Nucl. Med. Biol. 2014, 41, 203-209. [CrossRef] [PubMed] 